\title{
Biogeochemical factors affecting mercury methylation rate in two contaminated floodplain soils
}

\author{
T. Frohne ${ }^{1}$, J. Rinklebe ${ }^{1}$, U. Langer ${ }^{2}$, G. Du Laing ${ }^{3}$, S. Mothes ${ }^{4}$, and R. Wennrich ${ }^{4}$ \\ ${ }^{1}$ University of Wuppertal, Department D, Soil- and Groundwater-Management, Pauluskirchstraße 7, 42285 Wuppertal, \\ Germany \\ ${ }^{2}$ State Office for Environmental Protection of Saxony-Anhalt, Department of Soil Protection, Reideburger Straße 47, \\ 06116 Halle/Saale, Germany \\ ${ }^{3}$ Ghent University, Faculty of Bioscience Engineering, Coupure Links 653, 9000 Gent, Belgium \\ ${ }^{4}$ UFZ Helmholtz Centre for Environmental Research, Department of Analytical Chemistry, Permoserstraße 15, \\ 04318 Leipzig, Germany
}

Correspondence to: J. Rinklebe (rinklebe@uni-wuppertal.de)

Received: 27 June 2011 - Published in Biogeosciences Discuss.: 2 September 2011

Revised: 23 December 2011 - Accepted: 9 January 2012 - Published: 26 January 2012

\begin{abstract}
An automated biogeochemical microcosm system allowing controlled variation of redox potential $\left(\mathrm{E}_{\mathrm{H}}\right)$ in soil suspensions was used to assess the effect of various factors on the mobility of mercury $(\mathrm{Hg})$ as well as on the methylation of $\mathrm{Hg}$ in two contaminated floodplain soils with different $\mathrm{Hg}$ concentrations (approximately $5 \mathrm{mg} \mathrm{Hg} \mathrm{kg}^{-1}$ and $>30 \mathrm{mg} \mathrm{Hg} \mathrm{kg}^{-1}$ ). The experiment was conducted under stepwise variation from reducing (approximately $-350 \mathrm{mV}$ at $\mathrm{pH}$ 5) to oxidizing conditions (approximately $600 \mathrm{mV}$ at $\mathrm{pH}$ 5). Results of phospholipid fatty acids (PLFA) analysis indicate the occurrence of sulfate reducing bacteria (SRB) such as Desulfobacter species (10Me16:0, cy17:0, 10Me18:0, cy19:0) or Desulfovibrio species $(18: 2 \omega 6,9)$, which are considered to promote $\mathrm{Hg}$ methylation. The products of the methylation process are lipophilic, highly toxic methyl mercury species such as the monomethyl mercury ion $\left[\mathrm{MeHg}^{+}\right]$, which is named as $\mathrm{MeHg}$ here. The $\ln \left(\mathrm{MeHg} / \mathrm{Hg}_{\mathrm{t}}\right)$ ratio is assumed to reflect the net production of monomethyl mercury normalized to total dissolved $\mathrm{Hg}\left(\mathrm{Hg}_{\mathrm{t}}\right)$ concentration. This ratio increases with rising dissolved organic carbon (DOC) to $\mathrm{Hg}_{\mathrm{t}}$ ratio $\left(\ln \left(\mathrm{DOC} / \mathrm{Hg}_{\mathrm{t}}\right)\right.$ ratio) $\left(R^{2}=0.39, p<0.0001, n=63\right)$ whereas the relation between $\ln \left(\mathrm{MeHg} / \mathrm{Hg}_{\mathrm{t}}\right)$ ratio and $\operatorname{lnDOC}$ is weaker $\left(R^{2}=0.09\right.$; $p<0.05 ; n=63)$. In conclusion, the $\mathrm{DOC} / \mathrm{Hg}_{\mathrm{t}}$ ratio might be a more important factor for the $\mathrm{Hg}$ net methylation than DOC alone in the current study. Redox variations seem to affect the biogeochemical behavior of dissolved inorganic $\mathrm{Hg}$ species and $\mathrm{MeHg}$ indirectly through related changes
\end{abstract}

in DOC, sulfur cycle, and microbial community structure whereas $\mathrm{E}_{\mathrm{H}}$ and $\mathrm{pH}$ values, as well as concentration of dissolved $\mathrm{Fe}^{3+} / \mathrm{Fe}^{2+}$ and $\mathrm{Cl}^{-}$seem to play subordinate roles in $\mathrm{Hg}$ mobilization and methylation under our experimental conditions.

\section{Introduction}

Mercury $(\mathrm{Hg})$ is one of the most hazardous heavy metals, posing a risk to humans and environment (e.g. Wolfe et al., 1998; Gibicar et al., 2006; Bergeron et al., 2011). It is distributed widespread all over the world and can be found in various environmental compartments such as floodplains (e.g. Devai et al., 2005; Overesch et al., 2007; Rinklebe et al., 2009). Many floodplain soils have accumulated large amounts of $\mathrm{Hg}$ as a result of atmospheric deposition or through transport from the watershed (e.g. Boening, 2000; During et al., 2009; Rinklebe et al., 2010). Large floodplain areas along the Wupper River (Germany) are heavily polluted with $\mathrm{Hg}$ due to the discharge of waste originating from textile industry, particularly from dye factories, and metal industry during the last centuries.

The mobility, bioavailability, ecological and toxicological effects of $\mathrm{Hg}$ are strongly dependent on its chemical speciation (Ullrich et al., 2001). Methylation of inorganic $\mathrm{Hg}$ is an important process, which can fundamentally change its mobility, bioavailability, and toxicity (Boening, 2000). The 
products of this methylation process are lipophilic, highly toxic methyl mercury species such as dimethyl mercury $\left[\mathrm{Me}_{2} \mathrm{Hg}\right]$ or the monomethyl mercury ion $\left[\mathrm{MeHg}^{+}\right]$, which is named as $\mathrm{MeHg}$ in the following. Both methyl mercury species exhibit a significant risk to humans and wildlife due to its neurotoxicity and tendency to accumulate in the food chain (Wolfe et al., 1998; Boening, 2000; King et al., 2002; Li et al., 2010).

Generally, the mobility and methylation of $\mathrm{Hg}$ in frequently flooded soils is determined by a range of factors, such as redox potential $\left(\mathrm{E}_{\mathrm{H}}\right), \mathrm{pH}$, dissolved organic carbon (DOC), sulphur (S), chloride $\left(\mathrm{Cl}^{-}\right)$, iron $(\mathrm{Fe})$, and total dissolved $\mathrm{Hg}\left(\mathrm{Hg}_{\mathrm{t}}\right)$ content (e.g. Skyllberg et al., 2003; DeLaune et al., 2004; Sunderland et al., 2006). Dissolved organic carbon interacts strongly with $\mathrm{Hg}$ by the formation of Hg-DOC complexes (e.g. Ravichandran, 2004; Khwaja et al., 2006; Feyte et al., 2010). The high affinity of $\mathrm{Hg}$ to DOC can partly be attributed to the binding of $\mathrm{Hg}$ with reactive sulfur groups in the hydrophobic acid fraction of DOC (Karlsson and Skyllberg, 2003; Shanley et al., 2008).

Mercury immobilization can be induced under anoxic conditions due to the formation of hardly soluble $\mathrm{Hg}$ sulfides (e.g. Skyllberg et al., 2003; Du Laing et al., 2009). Sulfides $\left(\mathrm{S}^{2-}\right)$ are generated through sulfate $\left(\mathrm{SO}_{4}^{2-}\right)$ reduction, which is mainly catalyzed by microorganisms. Sulfate reducing bacteria (SRB) (e.g. Desulfovibrio desulfuricans, Desulfobulbus proprionicus) mediate the formation of $\mathrm{S}^{2-}$ as a result of respiration processes that require $\mathrm{SO}_{4}^{2-}$ as a terminal electron acceptor (King et al., 2002). During $\mathrm{Hg}$ methylation, microorganisms increase their resistance to $\mathrm{Hg}$ by rendering the $\mathrm{Hg}^{2+}$ ion ineffective in disturbing the normal biochemical processes within the cell (Boening, 2000). This methylation process has been found to be mainly conducted by SRB and Fe reducing bacteria (Compeau and Bartha, 1985; Macalady et al., 2000; Fleming et al., 2006; Merritt and Amirbahman, 2009). Furthermore, it might be possible that other organisms such as aerobic bacteria, fungi, and seaweed may play a role in $\mathrm{Hg}$ methylation as suggested for tropical environments and mangrove wetlands (CoelhoSouza et al., 2006; Wu et al., 2011). The microbial community composition in soils and sediments can be characterized by the analysis of phospholipid fatty acids (PLFA) (e.g. Macalady et al., 2000; Rinklebe and Langer, 2006; Langer and Rinklebe, 2009). This method allows identifying the presence of SRB (Taylor and Parkes, 1985; Coleman et al., 1993; Macalady et al., 2000).

Iron can influence the dynamics of $\mathrm{Hg}$ in soils. For instance, $\mathrm{Fe}$ (hydr)oxides are able to adsorb $\mathrm{Hg}$; thus, they can act as important $\mathrm{Hg}$ sinks (Fernandez-Martinez et al., 2006; Harris-Hellal et al., 2011). Moreover, the mobility and methylation of $\mathrm{Hg}$ can be influenced by $\mathrm{Cl}^{-}$, for example through the formation of $\mathrm{Hg}$ chloride or $\mathrm{MeHg}-\mathrm{Cl}$ complexes (Davis et al., 1997; Skyllberg et al., 2003).

Although the presence of $\mathrm{Hg}$ and $\mathrm{MeHg}$ in the environment has been frequently documented (e.g. van Faassen,
1975; Boening, 2000; Agusa et al., 2005; Devai et al., 2005; Gibicar et al., 2006), mechanistic experiments aimed to study the redox-induced mobilization and immobilization of $\mathrm{Hg}$ and $\mathrm{MeHg}$ as well as information on biogeochemical factors affecting the methylation rate of $\mathrm{Hg}$ in floodplain soils are very scarce up to date.

Thus, our aim was to assess the impact of $\mathrm{E}_{\mathrm{H}}, \mathrm{pH}, \mathrm{DOC}$, $\mathrm{SO}_{4}^{2-}, \mathrm{Fe}$, and $\mathrm{Cl}^{-}$on the mobility and methylation of $\mathrm{Hg}$ in two floodplain soils with different $\mathrm{Hg}$ contamination levels (approximately 5 and $>30 \mathrm{mg} \mathrm{Hg} \mathrm{kg}^{-1}$, respectively) under acidic to neutral $\mathrm{pH}$ conditions. Therefore, we used an automatic biogeochemical microcosm system allowing establishing definite, computer-controlled redox conditions in soil suspensions.

\section{Materials and methods}

\subsection{Study site}

Soil samples were collected from two floodplain soils (Wupper $1=\mathrm{W} 1$; Wupper $2=\mathrm{W} 2$ ) at the lower course of the Wupper River (Germany) close to the confluence into the Rhine River (Fig. 1). The study sites are located about $15-20 \mathrm{~km}$ to the north of Cologne, Germany, near the town Leverkusen, (W1: $51^{\circ} 4^{\prime} 0.48^{\prime \prime} \mathrm{N}, 6^{\circ} 59^{\prime} 0.77^{\prime \prime} \mathrm{E}$; W2: $\left.51^{\circ} 5^{\prime} 4.1^{\prime \prime} \mathrm{N}, 7^{\circ} 0^{\prime} 12.61^{\prime \prime} \mathrm{E}\right)$. The distance between the two study sites is about $2 \mathrm{~km}$. The long term average annual precipitation is approximately $800 \mathrm{~mm}$ and the long term average annual air temperature is $10.8^{\circ} \mathrm{C}$ (DWD, 2009). The geological parent material consists of sediments of the Rhine River ("Niederrheinische Bucht"), which is predominantly shale from Devonian origin ("Rheinisches Schiefergebirge"). The study sites are used as grassland and are flooded seasonally by the Wupper River, usually in springtime (Wupperverband, 2009). The Wupper River is approximately $115 \mathrm{~km}$ in longitude with an average gradient of $0.4 \%$. The discharge averages $15.4 \mathrm{~m}^{3} \mathrm{~s}^{-1}$. The catchment area of the Wupper River comprises $814 \mathrm{~km}^{2}$. Both soils are classified as Eutric Fluvisols (IUSS-ISRIC-FAO, 2006).

\subsection{Sampling, pre-treatment, and analysis of bulk soil}

Soil samples were collected from the genetic A-horizons ( 0 $10 \mathrm{~cm}$ for $\mathrm{W} 1 ; 0-32 \mathrm{~cm}$ for $\mathrm{W} 2$ ). Soil sampling was performed in four replicates of about $1 \mathrm{~kg}$ each which were merged to one sample. For chemical analysis, soil material was homogenized, air-dried, and sieved to $<2 \mathrm{~mm}$. Subsamples were ground in an agate disc mill. Physico-chemical soil properties were determined according to standard methods (Schlichting et al., 1995). Total C $\left(\mathrm{C}_{\mathrm{t}}\right)$ and total $\mathrm{N}\left(\mathrm{N}_{\mathrm{t}}\right)$ were determined via dry combustion and thermal conductivity detection using a C/N/S-Analyzer (Vario EL Heraeus, Analytik Jena, Germany). A C-MAT 550 (Stroehlein, Germany) was used to measure inorganic $\mathrm{C}$ by dry combustion and IRdetection. Soil organic $\mathrm{C}$ was calculated as the difference 


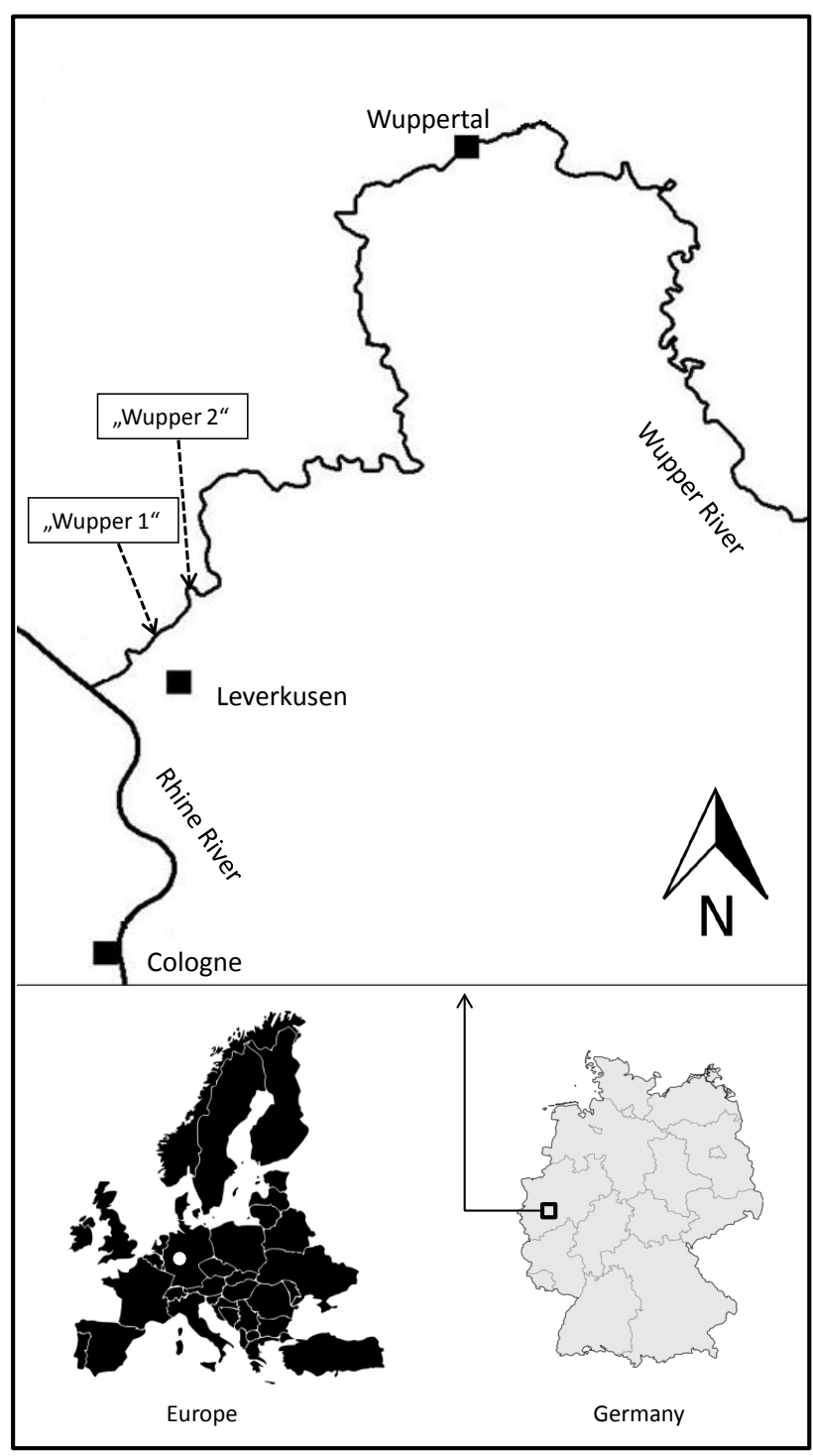

Fig. 1. Study site.

between $\mathrm{C}_{\mathrm{t}}$ and inorganic C. Particle-size distribution was measured using the pipette sampling technique by wet sieving and sedimentation (Blume et al., 2000). Total metal concentrations of the soil were quantified after digestion using aqua regia $\left(37 \% \mathrm{HCl}+65 \% \mathrm{HNO}_{3}\right.$, volume ratio $\left.3: 1\right)$ ignoring the immobile silica-bound fraction. Total $\mathrm{Hg}$ was analyzed by a cold vapor atomic absorption spectrometer (FIMS 400, Perkin Elmer, USA). The calibration range was 0.5$20 \mu \mathrm{g} 1^{-1}$. The dissolved samples were appropriate diluted for this calibration range using $0.01 \mathrm{M}$ nitric acid. Analytical accuracy was achieved by the use of certified reference material (IAEA 405, IAEA 433, NIST 2709, and LGC-6139). Inductively coupled plasma atomic emission detection (Ciros CCD, Spectro, Germany) was used for determination of Fe. For the determination of total $\mathrm{S}$, the soil was compressed to pellets and $\mathrm{S}$ was measured by energy dispersive $\mathrm{X}$-ray spectroscopy (XLAB 2000, Spectro, Germany). The calibration (using wax pellets) was done in the concentration range $0.0150-15 \mathrm{~g} \mathrm{~kg}^{-1}$. The following 15 reference materials had been used: GBW 7309-7312, GBW 7409-7411, LKSD 1, LKSD 4, NIST 2704, and NIST 2710.

For the soil microbial analysis (PLFA), fresh soil samples were sieved to $<2 \mathrm{~mm}$ and thereafter frozen at $-20^{\circ} \mathrm{C}$. After storage, samples were allowed to thaw at $4{ }^{\circ} \mathrm{C}$ for one day and $4 \mathrm{~h}$ at $20^{\circ} \mathrm{C}$ before analysis. Phospholipid extraction and PLFA analysis were performed following the standard procedure described by White et al. (1979) and Frostegård et al. (1991). Lipids were extracted with a modified singlephase mixture chloroform-methanol-citrate buffer (1:2:0.8 $\mathrm{v} / \mathrm{v} / \mathrm{v}$ ) (Bligh and Dyer, 1959). The resulting lipid material was fractionated into neutral lipids, glycolipids, and polar lipids by a silica-bonded phase column. The polar lipids were transesterified to the fatty acid methyl esters by a mild alkaline methanolysis (Guckert et al., 1985). Samples were analyzed by gas chromatography/mass spectroscopy using a Hewlett-Packard 6890 series gas chromatograph with a HP-5MS column $(60.0 \mathrm{~m}$ length, $0.25 \mathrm{~mm}$ internal diameter, coated with a cross-linked $5 \%$ phenyl methyl rubber phase with a film thickness of $0.25 \mu \mathrm{m}$ ) interfaced to an Agilent 5973 mass selective detector. The resulting chromatograms were evaluated by mass spectra, retention times, and nonadecanoic acid methyl ester (19:0) as the internal standard (N-5377, Sigma Chemical, Inc.). The analytical quality was confirmed by the repeated analysis of a standard bacterial acid methyl ester mix and a 37-component FAME mix (47080-U and 47885-U, Supelco, USA). PLFA were designated using the nomenclature described by Feng et al. (2003). More details regarding the method of PLFA analyses can be found in Rinklebe and Langer (2006) and Langer and Rinklebe (2009).

\subsection{Redox experiment}

\subsubsection{Biogeochemical microcosm system}

Flooding events were simulated using an automated biogeochemical microcosm system in the laboratory (Fig. 2). This system allows establishing pre-defined redox conditions in soil suspensions by flushing them with nitrogen $\left(\mathrm{N}_{2}\right)$ or oxygen $\left(\mathrm{O}_{2}\right)$. Thus, it is possible to study the effect of $\mathrm{E}_{\mathrm{H}}$ almost independent from other parameters. Recently this system was described in detail by Yu and Rinklebe (2011) and successfully used in previous studies for the investigation of trace gases (Yu et al., 2007), for the quantification of mercury emissions (Rinklebe et al., 2010), and for the determination of the dynamics of trace metals (Rupp et al., 2010; Frohne et al., 2011). The current study was conducted in four independent trials for each soil. The microcosms (MCs) were filled with $200 \mathrm{~g}$ air-dried soil and $1600 \mathrm{ml}$ deionized water. Homogenous conditions were reached by stirring the slurry 
continuously. Redox potential, $\mathrm{pH}$, and temperature in each MC were monitored every ten minutes by electrodes (Meinsberger Elektroden, Germany) and stored by a data logger. The $\mathrm{pH}$ values of $\mathrm{MC} 8$ and the $\mathrm{E}_{\mathrm{H}}$ values of $\mathrm{MC} 1$ after approximately $800 \mathrm{~h}$ incubation could not be monitored due to an error of the electrodes. The measured redox potential values were normalized to $\mathrm{pH} 5$, because the mean $\mathrm{pH}$ during the experiment was around 5 for both soils. Thus, the corrected values will be referred to as "E $\mathrm{HatpH}_{5}$ " in the following.

Straw and glucose were added to each MC to provide an additional source of organic matter for microorganisms. As a result, levels of $E_{\text {HatpH5 decreased (Fig. 4). This process }}$ was accelerated by continuously flushing the MCs with $\mathrm{N}_{2}$ for several days. When lowest $\mathrm{E}_{\mathrm{H}}$ values were reached, the first sample was taken from each MC. Thereafter, $\mathrm{E}_{\mathrm{H}^{-}}$ values were increased in steps of approximately $100 \mathrm{mV}$ by adding $\mathrm{O}_{2}$. Thereby, $\mathrm{E}_{\mathrm{H}}$ was kept within the set $\mathrm{E}_{\mathrm{H}}$-windows $\pm 10-20 \mathrm{mV}$ around the aimed value by supplying $\mathrm{O}_{2}$ or $\mathrm{N}_{2}$ automatically when the outer limits of the $\mathrm{E}_{\mathrm{H}}$-windows were exceeded. Redox potential was maintained for approximately $24 \mathrm{~h}$ within each window and afterwards set to the next window. Sampling was conducted approximately $24 \mathrm{~h}$ after reaching each new $\mathrm{E}_{\mathrm{H}}$-window (Fig. 4). The soil/water ratio remained the same during the experiment. After achieving the highest $\mathrm{E}_{\mathrm{H}}$ levels, $\mathrm{N}_{2}$ was added to lower $\mathrm{E}_{\mathrm{H}}$ again.

\subsubsection{Sample preparation, sub-sampling, and storage during the redox experiment}

The slurry in the MCs was sampled using a plastic syringe connected with a PTFE tube. The slurry samples were immediately centrifuged for $15 \mathrm{~min}$ at $3000 \mathrm{rpm}$. Afterwards, the supernatants were filtered through a $0.45 \mu \mathrm{m}$ Millipore membrane (Whatman Inc., Maidstone, UK) under $\mathrm{N}_{2}$-atmosphere. Thereafter, the filtrate (defined as the soluble fraction) was aliquoted to subsamples for subsequent analysis. For measuring $\mathrm{Hg}_{\mathrm{t}}$, the first $10 \mathrm{ml}$ subsample was preserved with $200 \mu \mathrm{l} 0.2 \mathrm{M}$ bromine monochloride solution $(\mathrm{BrCl})$ and stored at $8^{\circ} \mathrm{C}$ in bottles of acid rinsed borosilicate glass with PTFE-lined caps. A second subsample $(8 \mathrm{ml})$ was stored in acid rinsed glass bottles at $8^{\circ} \mathrm{C}$ for the analysis of $\mathrm{MeHg}$. Another $10 \mathrm{ml}$ subsample was stabilized by addition of $400 \mu \mathrm{l} 65 \% \mathrm{HNO}_{3}$ for analysis of total Fe and total S. Another subsample $(10 \mathrm{ml})$ was stored at $-20^{\circ} \mathrm{C}$ and gradually thawed for the determination of $\mathrm{DOC}, \mathrm{Cl}^{-}$, and $\mathrm{SO}_{4}^{2-}$.

\subsubsection{Chemical analyses of the redox experiment samples}

Total $\mathrm{Hg}$ was measured with cold vapor atomic fluorescence spectrometry (CV-AFS) (mercur duo plus, Analytik Jena, Germany). Mercury standard solutions were prepared by diluting mercury standard solution $1000 \mathrm{mg} \mathrm{l}^{-1} \mathrm{Hg}$ (CertiPur, Merck) with deionized water. A 7-point calibration curve

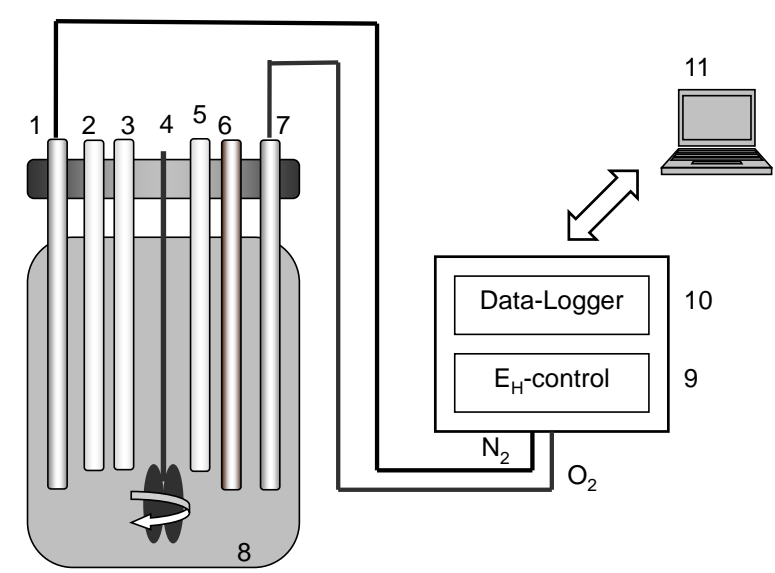

The soil microcosm system:

(1) dispersion tube for $\mathrm{N}_{2}$

(2) redox potential- $\left(E_{H}\right)$ electrode

(3) $\mathrm{pH}$ electrode

(4) stirrer

(5) thermometer

(6) sampling tube

(7) dispersion tube for $\mathrm{O}_{2}$

(8) glass vessel

(9) automatic $E_{H}$ regulation by $\mathrm{N}_{2}$ and $\mathrm{O}_{2}$ valves

(10) data logger $\left(E_{\mathrm{H}}, \mathrm{pH}\right.$, temperature)

(11) PC control for datalogger and valve system

Fig. 2. Biogeochemical microcosm setup.

including a blank sample was used for sample analysis. An intern reference sample was analyzed after every 10 samples to check the instrument drift. The drift was satisfying for all measurements. The detection limit was $10 \mathrm{ng} \mathrm{l}^{-1}$. The relative standard deviation of repeated measurements was below $3 \%$ for all samples.

The analyses of $\mathrm{MeHg}$ in the subsample were conducted by gas chromatography with atomic emission detection (GCAED). An amount of $2 \mathrm{ml}$ of the sample was spiked with $4 \mathrm{ml}$ buffer solution ( $\mathrm{pH} 4.5$ ) and $20 \mu \mathrm{Na}$-propylborat solution ( $2 \%$ in THF). The solution was stirred for $10 \mathrm{~min}$. The $\mathrm{Hg}$ species were enriched from the aqueous phase by solid phase microextraction (SPME) in the headspace mode. Analytes were enriched onto a $100 \mu \mathrm{m}$ polydimethylsiloxane (PDMS) - fibre for $30 \mathrm{~min}$ at a temperature of $30^{\circ} \mathrm{C}$. The prepared samples were stored at $15^{\circ} \mathrm{C}$ until measurement. Samples were processed automatically by a multipurpose sampler (MPS2, Gerstel, Mülheim, Germany) combined with a gas chromatograph Hewlett-Packard 6890 (Agilent, Waldbronn, Germany) and a microwave-induced plasma atomic emission detector jas 2350 (jas GmbH, Moers, Germany). Thermal desorption was carried out directly in the injector of the gas chromatograph for $1 \mathrm{~min}$ at $200^{\circ} \mathrm{C}$. The analyses were carried out using an HP1 column $(25 \mathrm{~m} \times 0.32 \mathrm{~mm} \times 0.17 \mu \mathrm{m})$ and $\mathrm{He}$ as carrier gas. Injection was performed in splitless 
mode and the oven was programmed from $40{ }^{\circ} \mathrm{C}(2 \mathrm{~min})$ to $280^{\circ} \mathrm{C}$ at $25^{\circ} \mathrm{C} \mathrm{min}^{-1}$. Reagent gases for the AED were $\mathrm{O}_{2}$ and $\mathrm{H}_{2}$, the make-up gas flow (He) was $130 \mathrm{ml} \mathrm{min}^{-1}$. The $\mathrm{Hg}$ emission line $254 \mathrm{~nm}$ was monitored. Only monomethyl mercury $\left(\mathrm{MeHg}^{+}\right)$- and no dimetyhl mercury $\left(\mathrm{Me}_{2} \mathrm{Hg}\right)-$ could be detected. The detection limit for $\mathrm{MeHg}^{+}$was $0.8 \mathrm{ng} \mathrm{Hg} 1^{-1}$. The calibration range was $1-100 \mathrm{ng} \mathrm{Hg}^{-1}$. Quality control was carried out using following reference materials: IAEA 405, IAEA 433, and CRM 462. Total Fe and $S$ were quantified by inductively coupled plasma optical emission spectrometry (ICP-OES) (Ultima 2, Horiba Scientific, Unterhaching, Germany). A four-point calibration was conducted by diluting single standard and multi element solutions (CertiPur, Merck) with deionized water. Analysis was conducted in three replications. The relative standard deviation of replicate analysis was below $5 \%$.

Dissolved organic carbon was measured after 2-point calibration with a TOC-analyzer (TOC- $\mathrm{V}_{\mathrm{E}}$, Shimadzu, Kyoto, Japan). Measurement was performed in two replications for each sample. The detection limit was $1 \mathrm{mgl}^{-1}$. Sulfate and $\mathrm{Cl}^{-}$were determined using an ion chromatograph (Personal IC 790, Metrohm, Filderstadt, Germany) with a Metrosep A Supp 4 - column. The detection limit was $0.03 \mathrm{mg} \mathrm{l}^{-1}$ for both ions.

\subsection{Calculations and statistical analysis}

Mean values of $\mathrm{E}_{\mathrm{H}}$ and $\mathrm{pH}$ data measured every 10 min originating from $3,6,12$, and $24 \mathrm{~h}$ periods prior to sampling were calculated. Values below the detection limit were excluded for the statistical analyses. Thereafter correlation and regression analyses between $\mathrm{Hg}_{\mathrm{t}}$ and $\mathrm{MeHg}$ on the one hand and $\mathrm{E}_{\mathrm{H}}, \mathrm{pH}, \mathrm{DOC}, \mathrm{SO}_{4}^{2-}, \mathrm{Cl}^{-}, \mathrm{Fe}$, and $\mathrm{S}$ on the other hand were conducted. Relations between $\mathrm{MeHg} / \mathrm{Hg}_{\mathrm{t}}$ and $\mathrm{DOC} / \mathrm{Hg}_{\mathrm{t}}$ on one hand and DOC and $\mathrm{Hg}_{\mathrm{t}}$ on the other hand were also calculated. Mean $\mathrm{E}_{\mathrm{H}}$ and $\mathrm{pH}$ values of the $6 \mathrm{~h}$ period prior to sampling were used because they revealed the highest regression coefficients in most cases. Correlation analysis was conducted by SPSS 19. ORIGIN 6.0 was used to calculate regressions and descriptive statistics. For regression analyses, the naturally logarithmised values (ln) of $\mathrm{Hg}_{\mathrm{t}}, \mathrm{MeHg}$, DOC, $\mathrm{Cl}^{-}, \mathrm{SO}_{4}^{2-}$, and $\mathrm{Fe}$ were taken, because the range of the values differed for several orders of magnitude. According to Fowler et al. (2006), the strength of the correlations was categorized in our study as follows: $r<0.20$ (corresponds to the coefficient of determination $R^{2}<0.04$ ) represent very weak correlations; $r$ between 0.20 and $0.39\left(R^{2}\right.$ between 0.04 and $0.15)$ weak correlations; $r$ between 0.4 and $0.69\left(R^{2}\right.$ between 0.16 and 0.48$)$ modest correlations; and $r>0.69\left(R^{2}>0.48\right)$ strong correlations.

\section{Results}

\subsection{Properties of the bulk soils}

Selected properties of the studied bulk soils are provided in Table 1. The soils of W1 and W2 mainly consist of sand and silt. The content of organic carbon is relatively high and the contents of inorganic carbon are $0.01 \%$ (W1) and $0.005 \%$ (W2). The pH is slightly acidic to neutral. Soil W1 is contaminated with approximately $5 \mathrm{mg} \mathrm{kg}^{-1} \mathrm{Hg}$, whereas soil W2 is higher contaminated and contains $>30 \mathrm{mg} \mathrm{Hg} \mathrm{kg}^{-1}$ (Table 1). For both soils, concentrations of $\mathrm{Hg}$ exceed the action value of $2 \mathrm{mg} \mathrm{Hg} \mathrm{kg}^{-1}$ set by the German Federal Soil Protection Ordinance (BBodSchV, 1999).

The results of PLFA analysis of the bulk soil are shown in Fig. 3. A total number of 26 PLFA (W1) and 20 PLFA (W2), respectively, were found in the soils. Here, those fatty acids which were previously identified as possible biomarkers for SRB are of particular interest. The fatty acids 15:0, 10Me16:0, cy17:0, 18:2 $\omega 6,9,10 \mathrm{Me} 18: 0$, and cy19:0 can serve as biomarkers for SRB (Taylor and Parkes, 1983; Kohring et al., 1994; Macalady et al., 2000). The fatty acids 10Me16:0 and cy19:0 revealed the highest values whereas cy17:0 and 10Me18:0 showed intermediate values in both soils. The PLFA 15:0 and 18:2 $\omega 6,9$ were low concentrated in the studied soils.

\subsection{Redox experiment}

The variations (mean, median, and range) of the measured parameters during the $\mathrm{E}_{\mathrm{H}}$ experiment are provided in Table 2 . The range was $0.09-8.27 \mu \mathrm{gl}^{-1}$ for $\mathrm{Hg}_{\mathrm{t}}$ and 1.3-101 $\mathrm{ng} 1^{-1}$. for $\mathrm{MeHg}$. The mean values were $0.99 \mu \mathrm{gl}^{-1}$ for $\mathrm{Hg}_{\mathrm{t}}$ and $14 \mathrm{ng}^{-1}$ for $\mathrm{MeHg}$. The $\mathrm{E}_{\mathrm{H}}$ ranges from $-335-601 \mathrm{mV}$ (all data). The $\mathrm{pH}$ ranges from 4.1-7.2 (all data) with mean values around 5 for both soils. During the experiment, $\mathrm{E}_{\mathrm{H}}$ and $\mathrm{pH}$ reveal a very weak significant negative correlation $\left(R^{2}=0.02 ; p<0.01 ; n=47,941\right)$. The development of $\mathrm{E}_{\mathrm{HatpH} 5}$ measured in the slurry every $10 \mathrm{~min}$ during the experiment and concentrations of $\mathrm{Hg}_{\mathrm{t}}$ in the soluble fraction at the sampling time are given in Fig. 4. The lowest $\mathrm{E}_{\mathrm{HatpH} 5}$ levels were around -150 and $0 \mathrm{mV}$ in MCs $1-4$ (W1) and between -100 and $-350 \mathrm{mV}$ in MCs 5-8 (W2). The highest $\mathrm{E}_{\mathrm{HatpH} 5}$ levels were around $500 \mathrm{mV}$ for $\mathrm{W} 1$ and $500-600 \mathrm{mV}$ for $\mathrm{W} 2$. The development of $\mathrm{pH}$ measured in the slurry every $10 \mathrm{~min}$ and the values of $\mathrm{MeHg}$ in the soluble fraction at the sampling points during the experiment are given in Fig. 5. The mean initial $\mathrm{pH}$ was $7.0 \pm 0.2$ for $\mathrm{W} 1$ (MCs 1-4) and $5.7 \pm 0.3$ for $\mathrm{W} 2$ (MCs 5-8). The $\mathrm{pH}$ dropped rapidly in all MCs to values between 4 and 5 . Afterwards, the pH slightly increased in all MCs when increasing the $\mathrm{E}_{\mathrm{H}}$ stepwise. A relationship between $\mathrm{Hg}_{\mathrm{t}}$ and $\mathrm{E}_{\mathrm{H}}$, or between $\mathrm{pH}$ and $\mathrm{MeHg}$ in the course of the experiment is not obvious (Figs. 4 and 5).

The $\ln \left(\mathrm{MeHg} / \mathrm{Hg}_{\mathrm{t}}\right)$ ratio revealed a modest positive relationship with $\ln \left(\mathrm{DOC} / \mathrm{Hg}_{\mathrm{t}}\right)\left(R^{2}=0.39 ; p<0.0001 ; n=63\right)$ 
Table 1. Selected properties of the studied soils $\left(\mathrm{C}_{\mathrm{org}}\right.$ : organic carbon, $\mathrm{N}_{\mathrm{t}}$ : total nitrogen) total metal concentrations (aqua regia soluble), and total sulfur (S) of the studied bulk soils Wupper 1 (W1) and Wupper 2 (W2).

\begin{tabular}{|c|c|c|c|c|c|c|c|c|c|c|}
\hline Soil & Depth [cm] & & Texture [\%] & & $\mathrm{C}_{\text {org }}$ & $\mathrm{N}_{\mathrm{t}}$ & $\mathrm{C}_{\mathrm{org}} \mathrm{N}_{\mathrm{t}}^{-1}$ & $\mathrm{Fe}$ & $\mathrm{Hg}$ & S \\
\hline & & $\begin{array}{c}\text { Sand } \\
0.063-2 \mathrm{~mm}\end{array}$ & $\begin{array}{c}\text { Silt } \\
0.002-0.063 \mathrm{~mm}\end{array}$ & $\begin{array}{c}\text { Clay } \\
<0.002 \mathrm{~mm}\end{array}$ & \multicolumn{2}{|c|}{$[\%]$} & & {$\left[\mathrm{g} \mathrm{kg}^{-1}\right]$} & \multicolumn{2}{|c|}{$\left[\mathrm{mg} \mathrm{kg}^{-1}\right]$} \\
\hline W1 & $0-10$ & 44 & 48 & 8 & 6.2 & 0.4 & 15.6 & 34 & 5.2 & 2060 \\
\hline W2 & $0-32$ & 55 & 36 & 9 & 7.9 & 0.4 & 19.8 & 49 & 31.5 & 2669 \\
\hline
\end{tabular}

W1

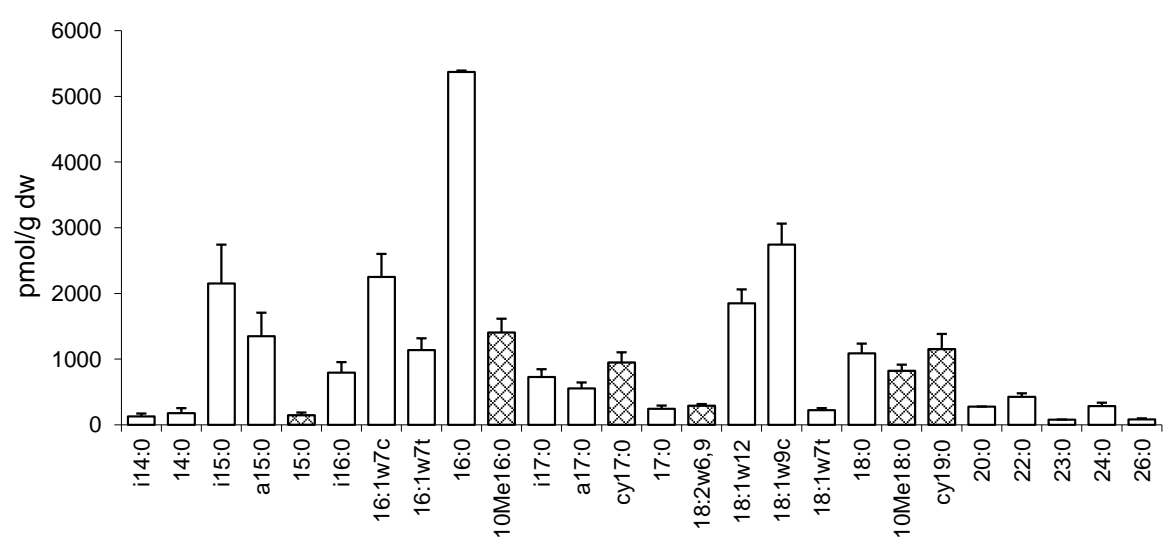

W2

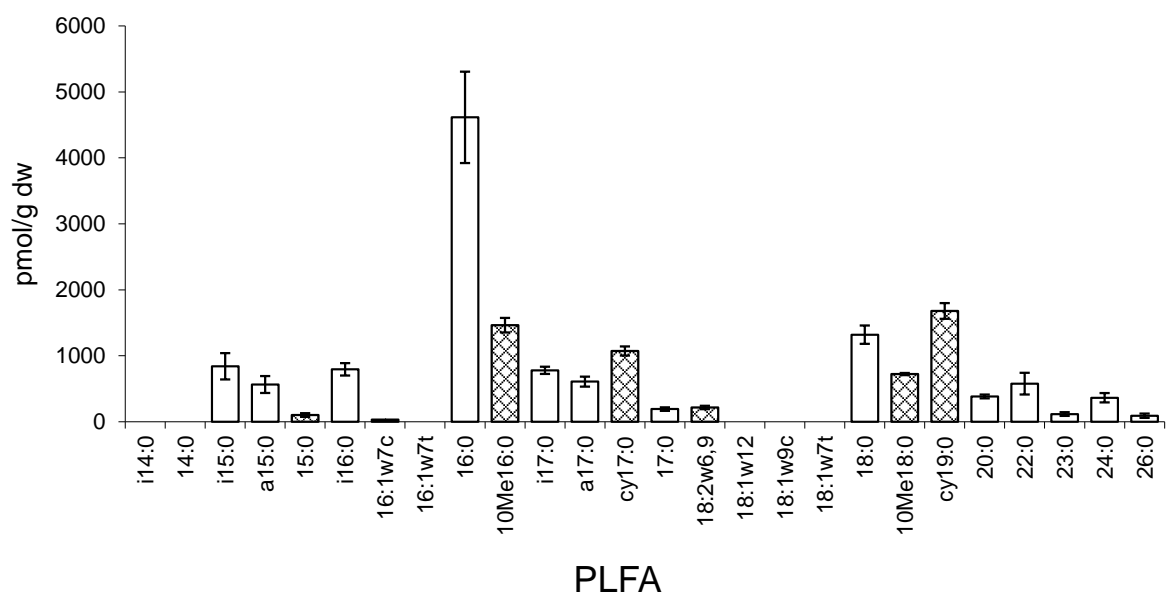

Fig. 3. Dry weight (dw) of phospholipid fatty acids (PLFA) in the bulk soils Wupper 1 (W1) and Wupper 2 (W2). Biomarkers for sulfate reducing bacteria are cross hatched.

(Fig. 6). There was a weaker negative relationship between $\ln \left(\mathrm{MeHg} / \mathrm{Hg}_{\mathrm{t}}\right)$ and $\operatorname{lnHg} g_{\mathrm{t}}\left(R^{2}=0.18 ; p<0.001 ; n=63\right)$ and a weak positive relation between $\ln \left(\mathrm{MeHg} / \mathrm{Hg}_{\mathrm{t}}\right)$ and $\operatorname{lnDOC}$ $\left(R^{2}=0.09 ; p<0.05 ; n=63\right)$. $\mathrm{LnHg}_{\mathrm{t}}$ values were correlated with $\ln \mathrm{MeHg}$ values and regression analysis showed a modest positive relationship $\left(R^{2}=0.16 ; p<0.005 ; n=63\right)$. Results of the regression analysis between $\operatorname{lnDOC}, \operatorname{lnCl}^{-}$, $\operatorname{lnSO}_{4}^{2-}, \mathrm{E}_{\mathrm{H}}, \operatorname{lnFe}, \mathrm{pH}$ and $\operatorname{lnHg}_{\mathrm{t}}$ on one hand and $\operatorname{lnMeHg}$ in the soluble fraction on the other hand are provided in Table 3. With the increase of $\mathrm{Hg}_{t}$ and $\mathrm{MeHg}, \mathrm{Cl}^{-}, \mathrm{SO}_{4}^{2-}$, and 
Table 2. Variations (mean, median, range) of concentrations of elements and compounds in the soluble fraction as well as $\mathrm{pH}$, and redox potential $\left(\mathrm{E}_{\mathrm{H}}\right)$ in the slurry.

\begin{tabular}{llllll}
\hline & & Mean & Median & Range & $\mathrm{n}$ \\
\hline $\mathrm{Hg}_{\mathrm{t}}$ & {$\left[\mu \mathrm{g} \mathrm{l}^{-1}\right]$} & 0.99 & 0.49 & $0.09-8.27$ & 65 \\
$\mathrm{MeHg}$ & {$\left[\mathrm{ng} \mathrm{l}^{-1}\right]$} & 14 & 5.8 & $1.3-101$ & 65 \\
\hline $\mathrm{E}_{\mathrm{H}}(6 \mathrm{~h})^{1,3}$ & & 230 & 297 & $-332-577$ & 67 \\
$\mathrm{E}_{\mathrm{H}(\text { all data })^{2,3}}$ & {$[\mathrm{mV}]$} & 239 & 319 & $-335-601$ & 53553 \\
\hline $\mathrm{pH}(6 \mathrm{~h})^{1}$ & & 5.0 & 5.0 & $4.4-6.2$ & 67 \\
$\mathrm{pH}(\text { all data })^{2}$ & & 5.5 & 5.2 & $4.1-7.2$ & 47941 \\
\hline $\mathrm{DOC}$ & & 2096 & 1989 & $1082-4463$ & 67 \\
$\mathrm{SO}_{4}^{2-}$ & & 32.0 & 8.6 & $2.2-223$ & 67 \\
$\mathrm{Cl}^{-}$ & {$\left[\mathrm{mg} \mathrm{l}^{-1}\right]$} & 584 & 144 & $72-3896$ & 67 \\
$\mathrm{~S}$ & & 2.1 & 2.0 & $0.7-7.7$ & 67 \\
$\mathrm{Fe}$ & & 199 & 114 & $0.2-553$ & 67 \\
\hline
\end{tabular}

1 means of data $6 \mathrm{~h}$ before sampling

2 data measured every 10 min during the experiment

${ }^{3} \mathrm{E}_{\mathrm{H}}$ corrected to $\mathrm{pH} 5$ (see Materials and Methods)

DOC in the soluble fraction increased. These correlations were strong for MeHg and DOC and modest for the other parameters. Iron was positively related to $\mathrm{MeHg}$ but not to $\mathrm{Hg}_{\mathrm{t}}$. Values of $\mathrm{pH}$ revealed a modest negative relation to $\mathrm{MeHg}$ and no correlation to $\mathrm{Hg}_{\mathrm{t}}$ (Table 3). Values of $\mathrm{E}_{\mathrm{H}}$ (Table 3) and $\mathrm{S}$ (data not given) are not related to $\mathrm{Hg}_{\mathrm{t}}$ or $\mathrm{MeHg}$. Values of $\mathrm{Cl}^{-}$and $\mathrm{SO}_{4}^{2-}$ in the soluble fraction were weakly associated with $\mathrm{E}_{\mathrm{HatpH} 5}$ (linear relationship with $R^{2}=0.15$; $p<0.01 ; n=67$ for $\mathrm{Cl}^{-}$and curved relationship $R^{2}=0.13$; $p<0.05 ; n=67$ for $\mathrm{SO}_{4}^{2-}$ respectively). Iron contents in the soluble fraction revealed a modest negative relationship to $\mathrm{E}_{\mathrm{HatpH5}}\left(R^{2}=0.33 ; p<0.001 ; n=67\right)$. Contents of DOC did not have a significant relationship with $\mathrm{E}_{\mathrm{HatpH} 5}$ (data not shown).

\section{Discussion}

\subsection{Direct impact of $\mathrm{E}_{\mathrm{H}}$ and $\mathrm{pH}$ on the mobility and methylation of $\mathrm{Hg}$}

The biogeochemical behavior and the dynamics of $\mathrm{Hg}$ and $\mathrm{MeHg}$ under changing redox conditions are affected by various factors. Our original hypothesis was that systematic changes of $E_{H}$ from anaerobic to aerobic conditions should have a considerable impact on the methylation of $\mathrm{Hg}$ since it has been reported that $\mathrm{MeHg}$ increases with decreasing $\mathrm{E}_{\mathrm{H}}$ (DeLaune et al., 2004; Sunderland et al., 2006). On the other hand, Ullrich et al. (2001) stated that anaerobic conditions might favor the reduction from $\mathrm{Hg}^{2+}$ to hardly soluble $\mathrm{Hg}^{0}$, which in turn may reduce $\mathrm{Hg}$ mobility and $\mathrm{Hg}$ methylation because of reduced bioavailability. However, in the current study, a direct impact of $\mathrm{E}_{\mathrm{H}}$ on $\mathrm{Hg}_{\mathrm{t}}$ or $\mathrm{MeHg}$ concentrations could not be detected (Figs. 4 and 5; Table 3). The variations of $\mathrm{Hg}_{\mathrm{t}}$ values during the experiment seem to be almost independent from $E_{H}$ variations (Fig. 4). Wallschläger et al. (1998) found consistent with our results, that the mobility of $\mathrm{Hg}$ is less influenced by changing redox conditions. Hintelmann and Wilken (1995) also reported that absolute $\mathrm{E}_{\mathrm{H}}$ might not be the most important factor regulating Hg methylation activity in anoxic sediments. The results of the current study appear to confirm those assumptions.

Redox potential has also an effect on the $\mathrm{pH}$. Generally it is well established that $\mathrm{pH}$ increases during reduction because reduction processes consume protons (e.g. Yu et al., 2007). Accordingly, a similar behavior was generally observed in our study. Literature data on effects of $\mathrm{pH}$ on the mobility and methylation of $\mathrm{Hg}$ are contradictory. Some authors found enhanced mobility and methylation of $\mathrm{Hg}$ at low pH (Boening, 2000; Ullrich et al., 2001; Wu et al., 2011). This was attributed to the fact that DOC is more positively charged at low $\mathrm{pH}$ and therefore has weaker tendencies to form complexes with $\mathrm{Hg}$, enhancing its availability for methylating bacteria (Ravichandran, 2004). This process could have occurred in the current study as well and might contribute to explain the modest negative relationship between $\mathrm{MeHg}$ and $\mathrm{pH}$ (Table 3). In contrast, low $\mathrm{pH}$ can decrease $\mathrm{Hg}$ methylation in anoxic sediments, maybe due to the suppression of bacterial activity at low $\mathrm{pH}$ (Gilmour and Henry, 1991). However, the results presented here show a less clear effect of $\mathrm{pH}$ on $\mathrm{Hg}_{\mathrm{t}}$ and on MeHg. Although the relationship between $\mathrm{MeHg}$ and $\mathrm{pH}$ is modest (Table 3), a mutual development between $\mathrm{MeHg}$ and $\mathrm{pH}$ is not obvious (Fig. 5) suggesting that additional factors are needed to explain $\mathrm{MeHg}$ variations. Accordingly, Wallschläger et al. (1996) have shown that the influence of $\mathrm{pH}$ on the solubility of $\mathrm{Hg}$ is relatively low compared to other metals (e.g. Cd, $\mathrm{Ni}, \mathrm{Co}, \mathrm{Zn}, \mathrm{Cu}, \mathrm{Pb}$ ). The direct impact of $\mathrm{E}_{\mathrm{H}}$ on the behavior of $\mathrm{Hg}$ and $\mathrm{MeHg}$ seems to be very weak in our study. Instead, indirect effects of $\mathrm{E}_{\mathrm{H}}$ and $\mathrm{pH}$ on the mobility and methylation of $\mathrm{Hg}$ through $\mathrm{E}_{\mathrm{H}}$ or $\mathrm{pH}$ related changes of other determining factors such as concentrations of DOC, $\mathrm{Fe}, \mathrm{Cl}^{-}$, and $\mathrm{SO}_{4}^{2-}$ should be more important under our experimental conditions.

\subsection{Impacts of $\mathrm{DOC}, \mathrm{Fe}, \mathrm{Cl}^{-}$, and $\mathrm{SO}_{4}^{2-}$ on the mobility and methylation of $\mathrm{Hg}$}

Total mercury and $\mathrm{MeHg}$ concentrations were positively related to DOC concentrations in the current experiment whereas this relationship is stronger between $\mathrm{MeHg}$ and DOC (Table 3). Similar results have been obtained by other authors (Covelli et al., 2009; Obrist et al., 2009; Feyte et al., 2010) since $\mathrm{Hg}$ and $\mathrm{MeHg}$ tend to form complexes with organic carbon. The interaction between DOC and $\mathrm{Hg}_{t}$ respectively $\mathrm{MeHg}$ can partly be attributed to the binding of $\mathrm{Hg}$ with reactive $\mathrm{S}$ groups in the dissolved organic molecules, especially in the hydrophobic acid fraction of DOC (Karlsson 

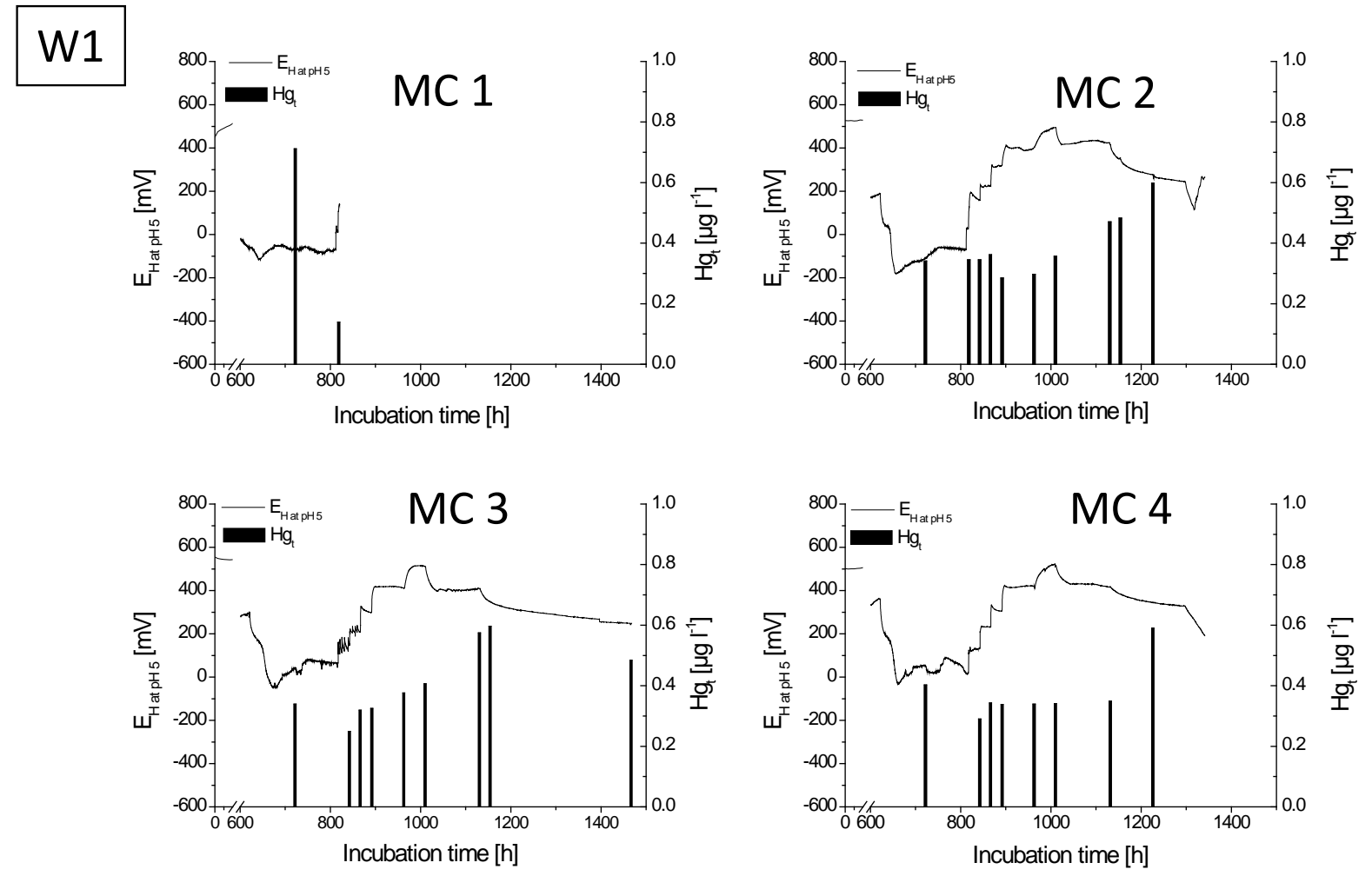

\section{W2}
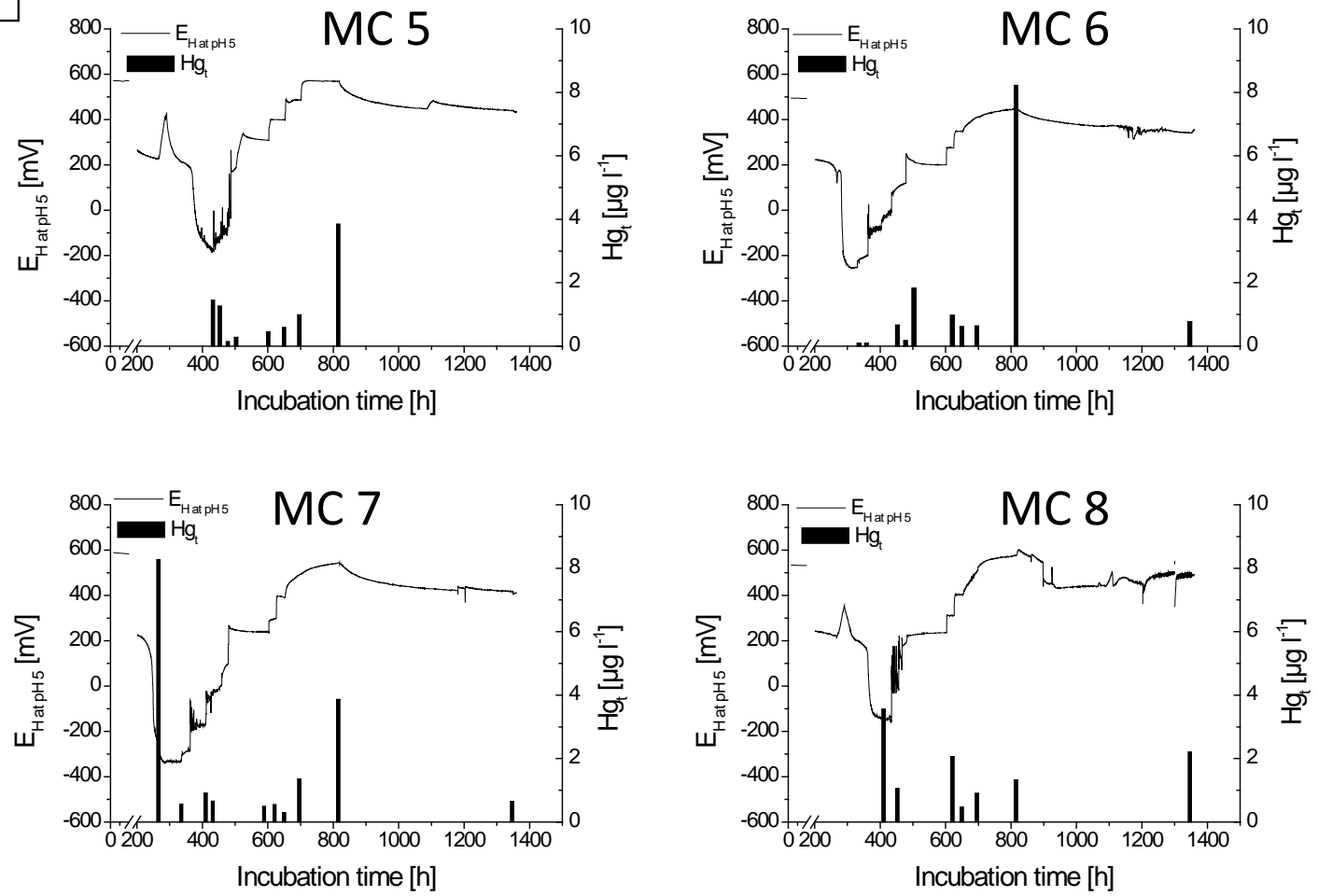

Fig. 4. $\mathrm{E}_{\mathrm{HatpH} 5}$ measured in the slurry every $10 \mathrm{~min}$ and $\mathrm{Hg}_{\mathrm{t}}$ concentrations in the soluble fraction during the experiment for each microcosm (MC) (Wupper 1 = W1, Wupper 2 = W2). 

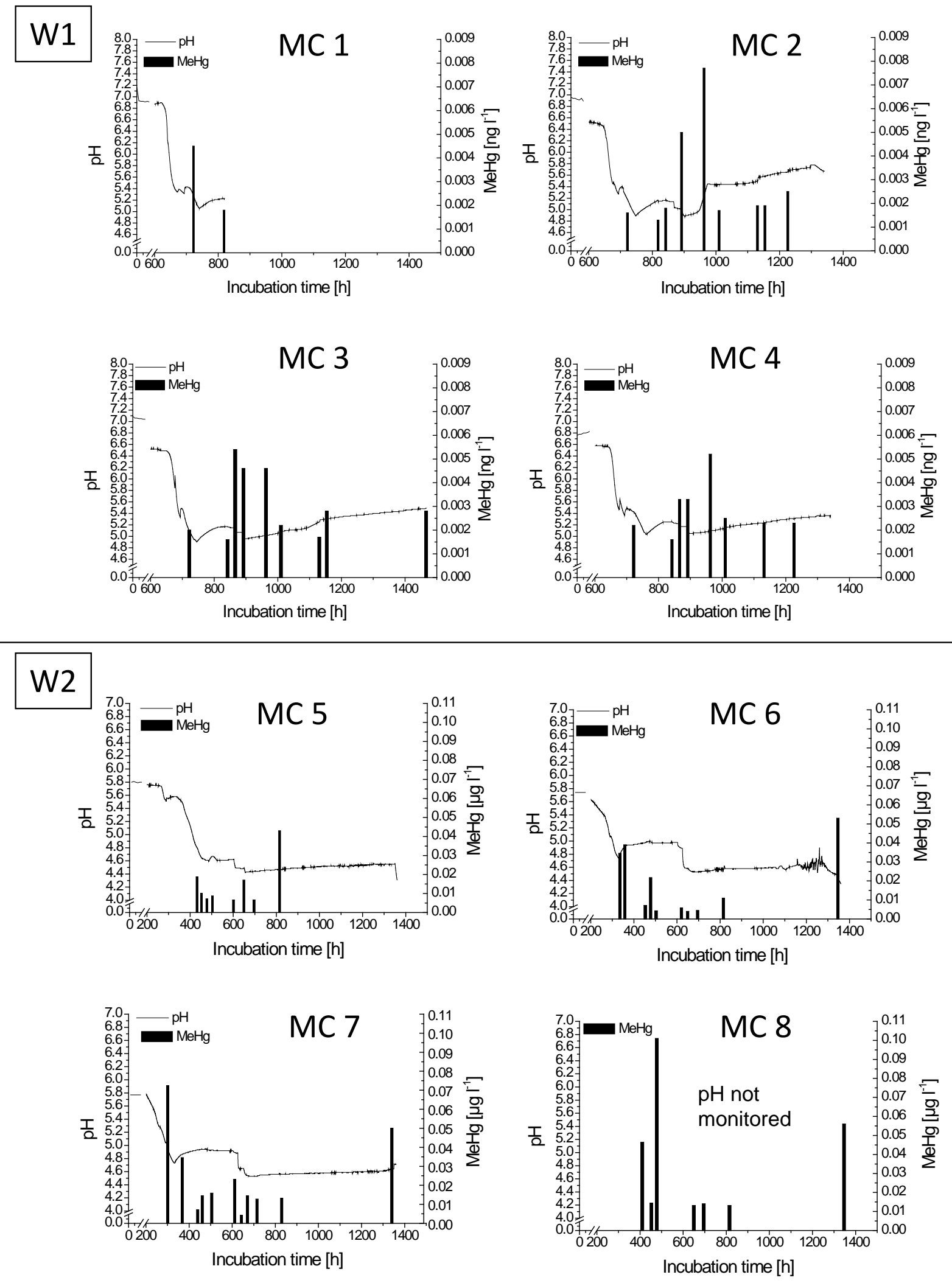

Fig. 5. Development of $\mathrm{pH}$ measured in the slurry every $10 \mathrm{~min}$ and $\mathrm{MeHg}$ concentrations in the soluble fraction during the experiment for each microcosm $(\mathrm{MC})($ Wupper $1=\mathrm{W} 1$, Wupper $2=\mathrm{W} 2)$. 
Table 3. Regressions between total mercury $\left(\mathrm{Hg}_{\mathrm{t}}\right)$ resp. methyl mercury $(\mathrm{MeHg})$ vs. anions $\left(\mathrm{Cl}^{-}, \mathrm{SO}_{4}^{2-}\right), \mathrm{DOC}, \mathrm{E}_{\mathrm{HatpH}}, \mathrm{Fe}$, and $\mathrm{pH}$ in the soluble fraction. (+) positive relationship; (-) negative relationship; ns $=$ not significant with $p \geq 0.05$.

\begin{tabular}{|c|c|c|c|}
\hline & & $\operatorname{lnHg}_{\mathrm{t}}$ & $\operatorname{lnMeHg}$ \\
\hline $\operatorname{lnDOC}$ & $\begin{array}{l}\text { regression equation } \\
R^{2} \\
p \\
n\end{array}$ & $\begin{array}{l}Y=7.674+0.209 X \\
\mathbf{0 . 2 6}(+) \\
<0.0001 \\
65\end{array}$ & $\begin{array}{l}Y=8.739+0.236 \mathrm{X} \\
\mathbf{0 . 5 3}(+) \\
<0.0001 \\
65\end{array}$ \\
\hline $\operatorname{lnSO} \mathrm{SO}_{4}^{2-}$ & $\begin{array}{l}\text { regression equation } \\
R^{2} \\
p \\
n\end{array}$ & $\begin{array}{l}Y=2.956+0.697 X \\
\mathbf{0 . 2 8}(+) \\
<0.0001 \\
65\end{array}$ & $\begin{array}{l}Y=4.962+0.473 X \\
\mathbf{0 . 2 0}(+) \\
<0.0005 \\
65\end{array}$ \\
\hline $\operatorname{lnCl}-$ & $\begin{array}{l}\text { regression equation } \\
R^{2} \\
p \\
n\end{array}$ & $\begin{array}{l}Y=5.900+0.687 \mathrm{X} \\
\mathbf{0 . 2 9}(+) \\
<0.0001 \\
65\end{array}$ & $\begin{array}{l}Y=7.716+0.433 X \\
\mathbf{0 . 1 8}(+) \\
<0.001 \\
65\end{array}$ \\
\hline $\operatorname{lnFe}$ & $\begin{array}{l}\text { regression equation } \\
R^{2} \\
p \\
n\end{array}$ & $\begin{array}{l}Y=3.979-0.330 X \\
0.02(n s) \\
0.236 \\
65\end{array}$ & $\begin{array}{l}Y=6.720+0.516 \mathrm{X} \\
\mathbf{0 . 0 8}(+) \\
<0.05 \\
65\end{array}$ \\
\hline $\mathrm{pH}$ & $\begin{array}{l}\text { regression equation } \\
R^{2} \\
p \\
n\end{array}$ & $\begin{array}{l}Y=4.957-0.0626 \mathrm{X} \\
0.03(\mathrm{~ns}) \\
0.19 \\
65\end{array}$ & $\begin{array}{l}Y=4.367-0.125 X \\
0.17(-) \\
<0.001 \\
65\end{array}$ \\
\hline $\mathrm{E}_{\text {HatpH5 }}$ & $\begin{array}{l}\text { regression equation } \\
R^{2} \\
p \\
n\end{array}$ & $\begin{array}{l}Y=249.201+29.990 X \\
0.01(\mathrm{~ns}) \\
0.36 \\
65\end{array}$ & $\begin{array}{l}\mathrm{Y}=-4.765-8.038 \mathrm{E}-4 \mathrm{X} \\
0.03(\mathrm{~ns}) \\
0.19 \\
65\end{array}$ \\
\hline
\end{tabular}

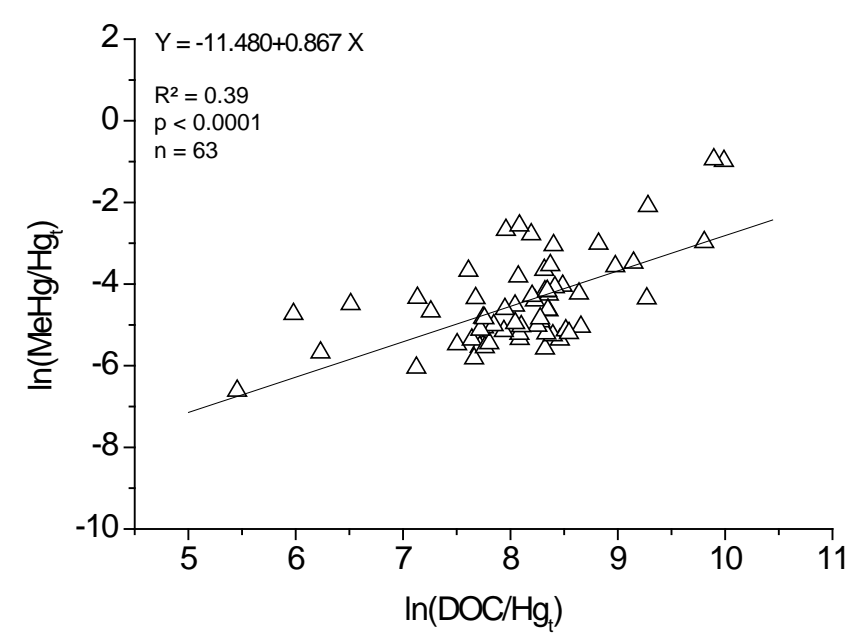

Fig. 6. Relation $\ln \left(\mathrm{MeHg} / \mathrm{Hg}_{\mathrm{t}}\right)$ vs. $\ln \left(\mathrm{DOC} / \mathrm{Hg}_{\mathrm{t}}\right)$ in the soluble fraction. and Skyllberg, 2003; Ravichandran, 2004; Khwaja et al., 2006; Shanley et al., 2008).

In addition to the impact of DOC due to a complexation of $\mathrm{Hg}_{\mathrm{t}}$ and $\mathrm{MeHg}$, a positive relationship between $\ln \left(\mathrm{MeHg} / \mathrm{Hg}_{\mathrm{t}}\right)$ and $\ln \left(\mathrm{DOC} / \mathrm{Hg}_{\mathrm{t}}\right)$ was found in our study (Fig. 6). The $\mathrm{MeHg} / \mathrm{Hg}_{\mathrm{t}}$ ratio is assumed to reflect the net production of $\mathrm{MeHg}$ normalized to the $\mathrm{Hg}$ concentration or the methylation efficiency respectively (Shanley et al., 2005; Skyllberg et al., 2007). Low $\mathrm{MeHg} / \mathrm{Hg}_{\mathrm{t}}$ ratios can be due to low $\mathrm{Hg}$ methylation or to high $\mathrm{MeHg}$ demethylation rates (Remy et al., 2006). Thus, increasing DOC/ $\mathrm{Hg}_{\mathrm{t}}$ ratio might have favored $\mathrm{Hg}$ net methylation or decreased demethylation in the current study. One reason for rising $\mathrm{DOC} / \mathrm{Hg}_{\mathrm{t}}$ ratio might be increasing DOC concentrations. In this case, increasing DOC could have promoted $\mathrm{Hg}$ net methylation or depressed demethylation in our study. Other studies have shown that high DOC contents can promote $\mathrm{Hg}$ methylation by enhanced SRB activity (see below), since DOC can serve as an important carbon source for bacteria (Davis et al., 1997; Ullrich et al., 2001; Lambertsson and Nilsson, 2006). Furthermore, DOC can contribute to abiotic methylation of 
Hg by donating methyl groups (Weber, 1993). However, abiotic methylation seems to be a process of minor importance compared to biological methylation (Avramescu et al., 2011). The positive relationship between $\ln \left(\mathrm{MeHg} / \mathrm{Hg}_{t}\right)$ and $\ln \left(\mathrm{DOC} / \mathrm{Hg}_{\mathrm{t}}\right)$ seems to be important in our experiment. In contrast, the relationship between $\ln \left(\mathrm{MeHg} / \mathrm{Hg}_{\mathrm{t}}\right)$ and $\operatorname{lnDOC}$ is weak, indicating that DOC alone might be a weaker factor in determining the $\mathrm{Hg}$ net methylation as also found by Skyllberg et al. (2003). Instead, the $\mathrm{DOC} / \mathrm{Hg}_{\mathrm{t}}$ ratio seems to play a more important role for $\mathrm{Hg}$ net methylation.

We also observed a negative relationship between $\ln \left(\mathrm{MeHg} / \mathrm{Hg}_{t}\right)$ and $\ln \mathrm{Hg}_{\mathrm{t}}$. A positive relationship was found between $\operatorname{lnHg}_{t}$ and $\operatorname{lnMeHg}$ as also reported by Sunderland et al. (2006) and Ouddane et al. (2008). Thus, increasing $\mathrm{Hg}_{\mathrm{t}}$ concentrations seem to have an inhibitory effect on $\mathrm{Hg}$ net methylation but may lead to higher total $\mathrm{MeHg}$ concentrations. High $\mathrm{Hg}$ concentrations can generally affect soil microorganisms in different ways. First, it is reported that high $\mathrm{Hg}_{\mathrm{t}}$ contents can exhibit toxic effects on methylating bacteria resulting in a depression of $\mathrm{MeHg}$ production (Ullrich et al., 2001). Secondly, microorganisms in $\mathrm{Hg}$ contaminated soils can be well adapted to Hg stress. This adaption can favor the selection of $\mathrm{Hg}$ tolerant bacteria in soils (Oliveira et al., 2010; Ruggiero et al., 2011). As a consequence, demethylation can be stimulated at high inorganic $\mathrm{Hg}$ concentrations by $\mathrm{Hg}$ tolerant bacteria which lead to reductive demethylation of $\mathrm{MeHg}$ (Schäfer et al., 2004). Bacterial $\mathrm{Hg}$ resistance is encoded by the mercury resistance (mer) operon encoding proteins that act amongst other factors in mercury detoxification. Most $\mathrm{Hg}$ resistant isolates contain merB (organomercury lyase), merA (mercuric reductase), merP, and merR genes (Lapanje et al., 2010; Ruggiero et al., 2011). Both toxic effects of $\mathrm{Hg}_{\mathrm{t}}$ on methylating bacteria and the occurrence of $\mathrm{Hg}$ tolerant bacteria might have occurred in the current study in parallel. However, the correlations between $\mathrm{Hg}_{\mathrm{t}}, \mathrm{MeHg}$, and $\mathrm{MeHg} / \mathrm{Hg}_{\mathrm{t}}$ are relatively low indicating that $\mathrm{Hg}_{\mathrm{t}}$ appears to have limited utility as a predictor of $\mathrm{Hg}$ net methylation and $\mathrm{MeHg}$ concentrations. This is in good agreement with Ouddane et al. (2008) who indicates that the production of $\mathrm{MeHg}$ is dependent on other parameters such as SRB in addition to total $\mathrm{Hg}$ concentrations in sediments with high $\mathrm{Hg}$ methylation activity.

Concentrations of $\mathrm{MeHg}$ and $\mathrm{Hg}_{\mathrm{t}}$ in the soluble fraction can also be influenced by the redox cycling of $\mathrm{S}$, which is abundant in both soils (Table 1). The relationships between $\mathrm{Hg}_{\mathrm{t}}$ and $\mathrm{SO}_{4}^{2-}$, and between $\mathrm{MeHg}$ and $\mathrm{SO}_{4}^{2-}$ are moderate (Table 3) what might indicate that both $\mathrm{Hg}_{t}$ and $\mathrm{MeHg}$ may be linked to the sulfur cycle. Brümmer (1974) mentioned that sulfides are generated from sulfates below $\mathrm{E}_{\mathrm{H}}-50 \mathrm{mV}$ at $\mathrm{pH}$ 7 (corresponds to $\mathrm{E}_{\mathrm{H}} 68 \mathrm{mV}$ at $\mathrm{pH}$ 5). As the $\mathrm{E}_{\mathrm{HatpH} 5}$ values fell below $68 \mathrm{mV}$ in all MCs during the incubation (Fig. 4), the formation of sulfides is most likely in our experiment. The soil slurries turned black and developed a typical odor with decreasing $\mathrm{E}_{\mathrm{H}}$, which also points towards the formation of sulfides. We did observe a correlation between $\mathrm{E}_{\mathrm{HatpH} 5}$ and $\mathrm{SO}_{4}^{2-}$. However, this relationship is weak and not linear. Relationships between $\mathrm{S}_{\mathrm{t}}$ and $\mathrm{E}_{\mathrm{HatpH}}, \mathrm{Hg}_{\mathrm{t}}$, or $\mathrm{MeHg}$ could not be found. One reason for that can be the rapid internal cycling of $\mathrm{S}$, which makes $\mathrm{SO}_{4}^{2-}$ concentrations a poor indicator for $\mathrm{SO}_{4}^{2-}$ reduction rates (Koretsky et al., 2007; $\mathrm{Yu}$ et al., 2007). When the concentration of reduced inorganic $S$ reaches a certain value the solubility and speciation of $\mathrm{Hg}^{2+}$ may be controlled by the precipitation of insoluble $\mathrm{HgS}$ or the formation of charged polysulfide $\mathrm{Hg}$-complexes as previously reported by several authors (e.g. Davis, 1997; Benoit et al., 2001; Du Laing et al., 2009). This may result in decreasing $\mathrm{Hg}$ concentrations in the dissolved phase when sulfates are removed from the dissolved phase upon reduction to sulfides. On the other hand, this may also result in the solubilisation of mercury upon oxidation of sulfides to sulfates under oxic conditions. Both processes may explain the positive correlations we observed between dissolved $\mathrm{SO}_{4}^{2-}$ and $\mathrm{Hg}_{\mathrm{t}}$ and $\mathrm{MeHg}$ concentrations. The formation of $\mathrm{HgS}$ at low $\mathrm{E}_{\mathrm{H}}$ can also decrease the availability of $\mathrm{Hg}^{2+}$ for methylation, consequently reducing $\mathrm{MeHg}$ production (Ullrich et al., 2001; Han et al., 2008). In contrast, reducing conditions can promote microbial mediated $\mathrm{S}$ reduction, which in turn can increase $\mathrm{Hg}$ methylation (Duran et al., 2008). In addition, high sulfide concentrations in marine environments containing organic matter seem to promote the uptake of $\mathrm{Hg}^{2+}$ by methylating bacteria such as sulfate reducing bacteria (SRB) maybe due to enhanced $\mathrm{Hg}$ bioavailability in mixed DOM-Hg-S complexes (Benoit et al., 2001; Sunderland et al., 2006). Sulfate reducing bacteria have been identified to be the principal methylators of inorganic $\mathrm{Hg}$ in sediments (Compeau and Bartha, 1985; King et al., 2002). The range of bacterial activity is large due to the variation in quantity and quality of organic matter, abundance of SRB, temperature, and $\mathrm{SO}_{4}^{2-}$ availability (Pallud and van Capellen, 2006). Various PLFA have been frequently used as biomarkers (e.g. SRB) to describe the microbial community structure in different environments (Taylor and Parkes, 1985; Coleman et al., 1993; Macalady et al., 2000; Wegener et al., 2008). The PLFA which might indicate the presence of Desulfobacter are 10Me16:0, cy 17:0, 10Me18:0, and cy19:0 (Kohring et al., 1994). Those PLFA were abundant in both studied soils (Fig. 3). The fatty acids 10Me16:0 and 10Me18:0 might serve as indicators for Desulfobacter and additionally for actinomycetes (Taylor and Parkes, 1983; Frostegård, 1993). The polyunsaturated fatty acid 18:2 $\omega 6,9$ might indicate the occurrence of Desulfovibrio (Macalady et al., 2000) or fungi (Frostegård, 1993). Desulfobulbus species are characterized by unbranched fatty acids such as 15:0 (Taylor and Parkes, 1983), which is widely distributed among different bacterial taxa (Macalady et al., 2000). Iron reducing bacteria such as Geobacter species are also able to methylate mercury in pure cultures at rates comparable to Desulfobulbus (Fleming et al, 2006; Kerin et al., 2006; Windham-Myers et al., 2009). Additionally, Avramescu et al. (2011) reported that 
Fe reduction through $\mathrm{Fe}$ reducing bacteria might decrease demethylation. According to Kohring et al. (1994), Geobacter metallireducens mainly consists of the PLFA 16:1 $\omega 7 \mathrm{c}$ and 16:0, which are abundant in our soils (Fig. 3). These PLFA can also be found in many other organisms (Zelles, 1997). However, we might speculate that Fe reducing bacteria could be present in our soils and therefore might also contribute to $\mathrm{Hg}$ methylation in the current study. The soil W1 contains a higher quantity of PLFA compared to W2, both in numbers ( $\mathrm{W} 1=26$; $\mathrm{W} 2=20)$ and in total PLFA biomass (W1 $\approx 27000 \mathrm{pmol} \mathrm{g}^{-1} ; \mathrm{W} 2 \approx 17000 \mathrm{pmol} \mathrm{g}^{-1}$ ). The number of PLFA which are related to SRB is 6 for both soils and the total biomass of these PLFA is approximately $5000 \mathrm{pmol} \mathrm{g}^{-1}$ for both soils. As measured by the total PLFA biomass, W1 contains $19 \%$ PLFA related to SRB whereas W2 contains $29 \%$ PLFA related to SRB. This indicates that $\mathrm{SRB}$ are more dominant at site W2. These values lead to the assumption that the relatively high $\mathrm{Hg}$ concentrations at the W2 site seem to have no direct toxic effect on SRB.

The statistical relationships between $\mathrm{Hg}_{t}$ and $\mathrm{Cl}^{-}$as well as between $\mathrm{MeHg}$ and $\mathrm{Cl}^{-}$are modest (Table 3) indicating that interrelations of these parameters might exist. Chloride can influence $\mathrm{Hg}$ speciation due to the competition of $\mathrm{Cl}^{-}$ with $\mathrm{Hg}_{\mathrm{t}}$ and $\mathrm{MeHg}$ for binding sites of soil particles, which can reduce $\mathrm{Hg}$ adsorption onto soil particles and promote the release of $\mathrm{Hg}$ into the aquatic phase (Yin et al., 1997; Liu et al., 2009). This process probably occurred in our study. Moreover, the behavior of $\mathrm{Hg}$ in the soluble fraction can partly be affected by the formation of $\mathrm{Hg}-\mathrm{Cl}$-complexes, which is relevant at $\mathrm{E}_{\mathrm{HatpH} 5}>500 \mathrm{mV}$ (Davis, 1997). Under the mostly acidic $\mathrm{pH}$ conditions which occurred in the current study, the formation of partly water soluble $\mathrm{HgCl}_{2}$ as well as nearly water insoluble $\mathrm{Hg}_{2} \mathrm{Cl}_{2}$ is possible (Davis, 1997; Ullrich et al., 2001). Generally, in solution [ $\mathrm{MeHg}] \mathrm{Cl}$ is formed in the presence of $\mathrm{Cl}^{-}$(Skyllberg et al., 2003). Thus, rising $\mathrm{Hg}_{\mathrm{t}}$ and $\mathrm{MeHg}$ concentrations with increasing $\mathrm{Cl}^{-}$concentrations in our study might indicate the formation of $\mathrm{Hg}-\mathrm{Cl}$ compounds probably mostly under aerobic conditions (Davis et al., 1997; Takeno, 2005). The weak relationship between $\mathrm{E}_{\mathrm{HatpH} 5}$ and $\mathrm{Cl}^{-}$reveals that $\mathrm{Cl}^{-}$concentrations are not decisively influenced by $\mathrm{E}_{\mathrm{H}}$.

In general, $\mathrm{Fe}$ (hydr)oxides are able to adsorb $\mathrm{Hg}$ to a certain extent (Fernandez-Martinez et al., 2006; Liu et al., 2009; Harris-Hellal et al., 2011). Moreover, Mehrotra and Sedlak (2005) explained decreased mercury methylation in anoxic wetland slurries upon amendment of $\mathrm{Fe}(\mathrm{II})$ by reduced availability of $\mathrm{Hg}$ for methylation due to the formation of $\mathrm{FeS}$ which subsequently decreased the pool of bioavailable neutral mercury-sulfide species. Hollweg et al. (2009) indicate that $\mathrm{Hg}$ interacts with inorganic sulfur ligands in FeS complexes decreasing the bioavailability of $\mathrm{Hg}$. In the current study, both soils contain considerable amounts of Fe (Table 1) and Fe(hydr)oxides should precipitate at high $\mathrm{E}_{\mathrm{H}}$ which is confirmed by the negative relationship between $\mathrm{Fe}$ in the soluble fraction and $\mathrm{E}_{\mathrm{HatpH} 5}$. However, no evidence was found in this study that $\mathrm{Hg}_{\mathrm{t}}$ was linked to the Fe cycle whereas MeHg showed a weak relationship to Fe (Table 3). This may be attributed to the fact that DOC competes with $\mathrm{Fe}$ (hydr)oxides for binding $\mathrm{Hg}$ and $\mathrm{MeHg}$ (Feyte et al., 2010) and the DOC contents were high in our study. Additionally, $\mathrm{pH}$ might be an important factor in this context, because $\mathrm{Hg}$ is only preferentially sorbed to Fe(hydr)oxides in the neutralalkaline pH-range (Ullrich et al., 2001). In summary, redox variations seem to affect the concentrations of dissolved $\mathrm{Hg}_{\mathrm{t}}$ and $\mathrm{MeHg}$ indirectly through related changes in DOC, sulfur cycle, and microbial interaction and community structure whereas $\mathrm{E}_{\mathrm{H}}$ and $\mathrm{pH}$ values, as well as concentration of dissolved $\mathrm{Fe}$ and $\mathrm{Cl}^{-}$seem to play subordinate roles in $\mathrm{Hg}$ mobilization and methylation under our experimental conditions.

\section{Conclusions}

In our $\mathrm{E}_{\mathrm{H}}$ experiment the $\ln \left(\mathrm{DOC} / \mathrm{Hg}_{\mathrm{t}}\right)$ ratio is positively correlated to net $\mathrm{MeHg}$ production. This indicates that the $\ln \left(\mathrm{DOC} / \mathrm{Hg}_{\mathrm{t}}\right)$ ratio seems to play an important role for the $\mathrm{Hg}$ net methylation. Dissolved organic carbon itself can mobilize $\mathrm{Hg}$ and $\mathrm{MeHg}$ due to the formation of soluble complexes. Mercury methylation also seems to be linked to the $S$ chemistry while the influence of $\mathrm{Fe}$ and $\mathrm{Cl}^{-}$on $\mathrm{Hg}$ methylation and speciation seems to be weak in our study. However, the methylation of $\mathrm{Hg}$ seems to be affected by the soil microbial community. On the one hand, $\mathrm{Hg}$ methylation might be favored by reducing conditions through enhanced microbial activity such as SRB bacteria, as indicated by the presence of the respective PLFA biomarkers. On the other hand, reducing conditions might lead to the formation of hardly available $\mathrm{HgS}$ what might contribute to a decrease of $\mathrm{MeHg}$ production. In conclusion, future studies on the fate of mercury in wetland soils should include silty and clayey soil material and should focus on the specific role of the soil microbial community structure.

\section{Supplementary material related to this article is available online at: http://www.biogeosciences.net/9/493/2012/ bg-9-493-2012-supplement.pdf.}

Acknowledgements. The authors thank M. Braun, S. Czickus, and C. Vandenhirtz for their technical assistance. Furthermore, we thank T. Labatzke and A. Becker (Analytik Jena AG) for their support in mercury analysis.

Edited by: S. Bouillon 


\section{References}

Agusa, T., Kunito, T., Iwata, H., Monirith, I., Tana, T. S., Subramanian, A., and Tanabe, S.: Mercury contamination in human hair and fish from Cambodia: levels, specific accumulation and risk assessment, Environ. Pollut., 134, 79-86, 2005.

Avramescu, M.-L., Yumvihoze, E., Hintelmann, H., Ridal, J., Fortin, D., and Lean, D. R. S.: Biogeochemical factors influencing net mercury methylation in contaminated freshwater sediments from the St. Lawrence River in Cornwall, Ontario, Canada, Sci. Tot. Environ., 409, 968-978, 2011.

BBodSchV: Directive of the execution of the federal protection act (Federal soil protection and hazardous waste directive - BBodSchV) (in German), Bundesgesetzblatt I, 1554-1582, 1999.

Benoit, J. M., Gilmour, C. C., and Mason, R. P.: The influence of sulfide on solid phase mercury bioavailability for methylation by pure cultures of Desulfobulbus propionicus (1pr3), Environ. Sci. Technol., 35, 127-132, 2001.

Bergeron, C. M., Hopkins, W. A., Todd, B. D., Hepner, M. J., and Unrine, J. M.: Interactive effects of maternal and dietary mercury exposure have latent and lethal consequences for amphibian larvae, Environ. Sci. Technol., 45, 3781-3787, 2011.

Bligh, E. and Dyer, W.: A rapid method of total lipid extraction and purification, Can. J. Physiol. Pharmacol., 37, 911-917, 1959.

Blume, H.-P., Deller, B., Furtmann, K., Leschber, R., Paetz, A., and Wilke, B.-M.: Handbuch der Bodenuntersuchung, Bd. 1 bis 7. DIN Vorschriften, Wiley-VCH, Weinheim, 2000.

Boening, D. W.: Ecological effects, transport, and fate of mercury: a general review, Chemosphere, 40, 1335-1351, 2000.

Brümmer, G.: Redoxpotentiale und Redoxprozesse von Mangan-, Eisen- und Schwefelverbindungen in hydromorphen Böden und Sedimenten, Geoderma, 12, 207-222, 1974.

Coelho-Souza, S. A., Guimaraes, J. R. D., Mauro, J. B. N., Miranda, M. R., and Azevedo, S. M. F. O.: Mercury methylation and bacterial activity associated to tropical phytoplankton, Sci. Tot. Environ., 364, 188-199, 2006.

Coleman, M. L., Hedrick, D. B., Lovley, D. R., White, D. C., and Pye, K.: Reduction of Fe(III) in sediments by sulfate-reducing bacteria, Nature, 361, 436-438, 1993.

Compeau, G. C. and Bartha, R.: Sulfate-Reducing Bacteria: Principal Methylators of Mercury in Anoxic Estuarine Sediment, Appl. Environ. Microb., 50, 498-502, 1985.

Covelli, S., Acquavita, A., Piani, R., Predonzani, S., and De Vittor, C.: Recent contamination of mercury in an estuarine environment (Marano lagoon, Northern Adriatic, Italy), Estuar. Coast. Shelf S., 82, 273-284, 2009.

Davis, A., Bloom, N. S., and Que Hee, S. S.: The environmental geochemistry and bioaccessibility of mercury in soils and sediments: A review, Risk Anal., 17, 557-569, 1997.

DeLaune, R. D., Jugsujinda, A., Devai, I., and Patrick Jr., W. H.: Relationship of sediment redox conditions to methyl mercury in surface sediment of Louisiana lakes, J. Environ. Sci. Heal. A, 39, 1925-1933, 2004.

Devai, I., Patrick, W. H., Neue, H.-U., DeLaune, R. D., Kongchum, M., and Rinklebe, J.: Methyl Mercury and Heavy Metal Content in Soils of Rivers Saale and Elbe (Germany), Anal. Lett., 38, 1037-1048, 2005.

Du Laing, G., Rinklebe, J., and Vandecasteele, B.: Trace metal behaviour in estuarine and riverine floodplain soils and sediments: a review, Sci. Tot. Environ., 407, 3972-3985, 2009.
Duran, R., Ranchou-Peyruse, M., Menuet, V., Monperrus, M., Bareille, G., Goni, M. S., Salvado, J. C., Amouroux, D., Guyoneaud, R., Donard, O. F. X., and Caumette, P.: Mercury methylation by a microbial community from sediments of the Adour Estuary (Bay of Biscay, France), Environ. Pollut., 156, 951-958, 2008.

During, A., Rinklebe, J., Böhme, F., Wennrich, R., Stärk, H.-J., Mothes, S., Du Laing, G., Schulz, E., and Neue, H.-U.: Mercury Volatilization from Three Floodplain Soils at the Central Elbe River (Germany), Soil Sediment Contam.: Int. J., 18, 429-444, 2009.

DWD (Deutscher Wetterdienst): Wetter und Klima Deutscher Wetterdienst - Klimadaten, http://www.dwd. de/bvbw/appmanager/bvbw/dwdwwwDesktop?_nfpb= true\&pageLabel=_wdwww_klima_umwelt_klimadaten deutschland\&T82002gsbDocumentPath=Navigation $\{\%\}$ FOeffentlichkeit $\{\%\} 2 F K l i m a \_U m w e l t\{\%\} 2 F K l i m a d a t e n\{\%\}$ 2Fkldaten_kostenfrei $\{\%\} 2$ Fausgabe_mittelwerte_node. html_nnn\{\%\}3Dtrue, Cited 2 December 2009.

Feng, Y., Motta, A., Reeves, D., Burmester, C., van Santen, E., and Osborne, J.: Soil microbial communities under conventional-till and no-till continuous cotton systems, Soil Biol. Biochem., 35, 1693-1703, 2003.

Fernandez-Martinez, R., Loredo, J., Ordonez, A., and Rucandio, M. I.: Physicochemical characterization and mercury speciation of particle-size soil fractions from an abandoned mining area in Mieres, Asturias (Spain), Environ. Pollut., 142, 217-226, 2006.

Feyte, S., Tessier, A., Gobeil, C., and Cossa, D.: In situ adsorption of mercury, methylmercury and other elements by iron oxyhydroxides and organic matter in lake sediments, Appl. Geochem., 25, 984-995, 2010.

Fleming, E. J., Mack, E. E., Green, P. G., and Nelson, D. C.: Mercury Methylation from Unexpected Sources: MolybdateInhibited Freshwater Sediments and an Iron-Reducing Bacterium, Appl. Environ. Microb., 72, 457-464, 2006.

Fowler, J., Cohen, L., and Jarvis, P.: Practical Statistics for Field Biology, Wiley, Chichester, 2006.

Frohne, T., Rinklebe, J., Diaz-Bone, R. A., and Du Laing, G.: Controlled variation of redox conditions in a floodplain soil: Impact on metal mobilization and biomethylation of arsenic and antimony, Geoderma, 160, 414-424, 2011.

Frostegård, A., Tunlid, A., and Bååth, E.: Microbial biomass measured as total lipid phosphate in soils of different organic content, J. Microbiol. Meth., 14, 151-163, 1991.

Frostegård, A., Tunlid, A., and Bååth, E.: Phospholipid Fatty Acid Composition, Biomass, and Activity of Microbial Communities from Two Soil Types Experimentally Exposed to Different Heavy Metals, Appl. Environ. Microb., 59, 3605-3617, 1993.

Gibicar, D., Horvat, M., Nakou, S., Sarafidou, J., and Yager, J.: Pilot study of intrauterine exposure to methylmercury in Eastern Aegean islands, Greece, Sci. Tot. Environ., 367, 586-595, 2006.

Gilmour, C. C. and Henry, E. A.: Mercury methylation in aquatic systems affected by acid deposition, Environ. Pollut., 71, 131169, 1991.

Guckert, J. B., Antworth, C. P., Nichols, P. D., and White, D. C.: Phospholipid, ester-linked fatty acid profiles as reproducible assays for changes in procaryotic community structure of estuarine sediments, FEMS Microbiol. Ecol., 31, 147-158, 1985. 
Han, S., Obraztsova, A., Pretto, P., Deheyn, D. D., Gieskes, J., and Tebo, B. M.: Sulfide and iron control on mercury speciation in anoxic estuarine sediment slurries, Mar. Chem., 111, 214-220, 2008.

Harris-Hellal, J., Grimaldi, M., Garnier-Zarli, E., and Bousserrhine, N.: Mercury mobilization by chemical and microbial iron oxide reduction in soils of French Guyana, Biogeochemistry, 103, 223234, 2011

Hintelmann, H. and Wilken, R.-D.: Levels of total mercury and methylmercury compounds in sediments of the polluted Elbe River: influence of seasonally and spatially varying environmental factors, Sci. Tot. Environ., 166, 1-10, 1995.

Hollweg, T. A., Gilmour, C. C., and Mason, R. P.: Methylmercury production in sediments of Chesapeake Bay and the mid-Atlantic continental margin, Mar. Chem., 114, 86-101, 2009.

IUSS-ISRIC-FAO: World reference base for soil resources. A framework for international classification, correlation and communication, World Soil Resources Reports, 103, 128 S., Rome (FAO), 2006.

Karlsson, T. and Skyllberg, U.: Bonding of ppb levels of methyl mercury to reduced sulfur groups in soil organic matter, Environ. Sci. Technol., 37, 4912-4918, 2003.

Kerin, E. J., Gilmour, C. C., Roden, E., Suzuki, M. T., Coates, J. D., and Mason, R. P.: Mercury Methylation by Dissimilatory Iron-Reducing Bacteria, Appl. Environ. Microb., 72, 7919-7921, 2006.

Khwaja, A. R., Bloom, P. R., and Brezonik, P. L.: Binding Constants of Divalent Mercury $\left(\mathrm{Hg}^{2+}\right)$ in Soil Humic Acids and Soil Organic Matter Environ. Sci. Technol., 40, 844-849, 2006.

King, J. K., Harmon, S. M., Fu, T. T., and Gladden, J. B.: Mercury removal, methylmercury formation, and sulfate-reducing bacteria profiles in wetland mesocosms, Chemosphere, 46, 859-870, 2002.

Kohring, L. L., Ringelberg, D. B., Devereux, R., Stahl, D. A., Mittelman, M. W., and White, D. C.: Comparison of phylogenetic relationships based on phospholipid fatty acid profiles and ribosomal RNA sequence similarities among dissimilatory sulfatereducing bacteria, FEMS Microbiol. Lett., 119, 303-308, 1994.

Koretsky, C. M., Haveman, M., Beuving, L., Cuellar, A., Shattuck, T., and Wagner, M.: Spatial variation of redox and trace metal geochemistry in a minerotrophic fen, Biogeochemistry, 86, 3362, 2007.

Lambertsson, L. and Nilsson, M.: Organic material: The primary control on mercury methylation and ambient methyl mercury concentrations in estuarine sediments, Environ. Sci. Technol., 40, 1822-1829, 2006.

Langer, U. and Rinklebe, J.: Lipid biomarkers for assessment of microbial communities in floodplain soils of the Elbe River (Germany), Wetlands, 29, 353-362, 2009.

Lapanje, A., Zrimec, A., Drobne, D., and Rupnik, M.: Long-term $\mathrm{Hg}$ pollution-induced structural shifts of bacterial community in the terrestrial isopod (Porcellio scaber) gut, Environ. Pollut., 158, 3186-3193, 2010.

Li, P., Feng, X., and Qiu, G.: Methylmercury exposure and health effects from rice and fish consumption: A review, Int. J. Environ. Res. Public Health, 7, 2666-2691, 2010.

Liu, G., Cai, Y., Mao, Y., Scheidt, D., Kalla, P., Richards, J., Scinto, L. J., Tachiev, G., Roelant, D., and Appleby, C.: Spatial variability in mercury cycling and relevant biogeochemical controls in the Florida Everglades, Environ. Sci. Technol., 43, 4361-4366, 2009.

Macalady, J., Mack, E. E., Nelson, D. C., and Scow, K. M.: Sediment Microbial Community Structure and Mercury Methylation in Mercury-Polluted Clear Lake, California, Appl. Environ. Microb., 66, 1479-1488, 2000.

Mehrotra, A. S. and Sedlak, D. L.: Decrease in net mercury methylation rates following iron amendment to anoxic wetland sediment slurries, Environ. Sci. Technol., 39, 2564-2570, 2005.

Merritt, K. A. and Amirbahman, A.: Mercury methylation dynamics in estuarine and coastal marine environments - A critical review, Earth-Science reviews, 96, 54-86, 2009.

Obrist, D., Johnson, D. W., and Lindberg, S. E.: Mercury concentrations and pools in four Sierra Nevada forest sites, and relationships to organic carbon and nitrogen, Biogeosciences, 6, 765777, doi:10.5194/bg-6-765-2009, 2009.

Ouddane, B., Mikac, N., Cundy, A. B., Quillet, L., and Fischer, J. C.: A comparative study of mercury distribution and methylation in mudflats from two microtidal estuaries: The Seine (France) and the Medway (United Kingdom), Appl. Geochem., 23, 618631, 2008.

Oliveira, A., Pampulha, M. E., Neto, A. C., and Almeida, A. C.: Mercury tolerant diazotrophic bacteria in a long-term contaminated soil, Geoderma, 154, 359-363, 2010.

Overesch, M., Rinklebe, J., Broll, G., and Neue, H.-U.: Metals and arsenic in soils and corresponding vegetation at Central Elbe river floodplains (Germany), Env. Poll., 145, 800-812, 2007.

Pallud, C. and Van Capellen, P.: Kinetics of microbial sulfate reduction in estuarine sediments, Geochim. Cosmochim. Ac., 70, 1148-1162, 2006.

Ravichandran, M.: Interactions between mercury and dissolved organic matter-a review, Chemosphere, 55, 319-331, 2004.

Remy, S., Prudent, P., and Probst, J.-L.: Mercury speciation in soils of the industrialised Thur River catchment (Alsace, France), Appl. Geochem., 21, 1855-1867, 2006.

Rinklebe, J. and Langer, U.: Microbial diversity in three floodplain soils at the Elbe River (Germany), Soil Biol. Biochem., 38, 2144-2151, 2006.

Rinklebe, J., During, A., Overesch, M., Wennrich, R., Stärk, H.-J., Mothes, S., and Neue, H.-U.: Optimization of the simple field method to determine mercury volatilization from soils - Examples of 13 sites in floodplain ecosystems at the Elbe River (Germany), Ecol. Eng., 35, 319-328, 2009.

Rinklebe, J., During, A., Overesch, M., Du Laing, G., Wennrich, R., Stärk, H.-J., and Mothes, S.: Dynamics of mercury fluxes and their controlling factors in large $\mathrm{Hg}$-polluted floodplain areas, Environ. Pollut., 158, 308-318, 2010.

Ruggiero, P., Terzano, R., Spagnuolo, M., Cavalca, L., Colombo, M., Andreoni, V., Rao, M. A., Perucci, P., and Monaci, E.: Hg bioavailability and impact on bacterial communities in a longterm polluted soil, J. Environ. Monitor., 13, 145-156, 2011.

Rupp, H., Rinklebe, J., Bolze, S., and Meissner, R.: A scaledepended approach to study pollution control processes in wetland soils using three different techniques, Ecol. Eng., 36, 14391447, 2010.

Schäfer, J. K., Yagi, J., Reinfelder, J. R., Cardona, T., Ellickson, K. M., Tel-Or, S., and Barkay, T.: Role of the Bacterial Organomercury Lyase (MerB) in Controlling Methylmercury Accumulation in Mercury-Contaminated Natural Waters, Environ. Sci. Tech- 
nol., 38, 4304-4311, 2004.

Schlichting, E., Blume, H.-P., and Stahr, K.: Bodenkundliches Praktikum, Blackwell, Berlin, 1995.

Shanley, J. B., Kamman, N. C., Clair, T. A., and Chalmers, A.: Physical controls on total and methylmercury concentrations in streams and lakes of the northeastern USA, Ecotox., 14, 125$134,2005$.

Shanley, J. B., Mast, M. A., Campbell, D. H., Aiken, G. R., Krabbenhoft, D. P., Hunt, R. J., Walker, J. F., Schuster, P. F., Chalmers, A., Aulenbach, B. T., Peters, N. E., MarvinDiPasquale, M., Clow, D. W., and Shafer, M. M.: Comparison of total mercury and methylmercury cycling at five sites using the small watershed approach, Environ. Pollut., 154, 143-154, 2008.

Skyllberg, U., Qian, J., Frech, W., Xia, K., and Bleam, W. F.: Distribution of mercury, methyl mercury and organic sulphur species in soil, soil solution and stream of a boreal forest catchment, Biogeochemistry , 64, 53-76, 2003.

Skyllberg, U., Drott, A., Lambertsson, L., Björn, E., Karlsson, T., Johnson, T., Heinemo, S. A., and Holmström, H.: Net methylmercury production as a basis for improved risk assessment of mercury-contaminated sediments, Ambio, 36, 437-442, 2007.

Sunderland, E. M., Gobas, F. A. P. C., Branfireun, B. A., and Heyes, A.: Environmental controls on the speciation and distribution of mercury in coastal sediments, Mar. Chem., 102, 111-123, 2006.

Takeno, N.: Atlas of Eh-pH diagrams, Intercomparison of thermodynamic databases, Geological Survey of Japan Open File Report, 419, http://www.gsj.jp/GDB/openfile/files/no0419/ openfile419e.pdf, cited 08 June 2011, 2005.

Taylor, J. and Parkes, R. J.: The Cellular Fatty Acids of the Sulphate-reducing Bacteria Desulfobacter sp., Desulfobulbus sp. and Desulfovibvio desulfuvicans, J. Gen. Microbiol., 129, 33033309, 1983.

Taylor, J. and Parkes, R. J.: Identifying Different Populations of Sulphate-reducing Bacteria within Marine Sediment Systems, Using Fatty Acid Biomarkers, J. Gen. Microbiol., 131, 631-642, 1985.

Ullrich, S. M., Tanton, T. W., and Abdrashitova, S. A.: Mercury in the aquatic environment: A review of factors affecting methylation, Crit. Rev. Env. Sci. Tech., 31, 241-293, 2001.

Van Faassen, H. G.: Short communication - Methylation of mercury compounds in soil, sediment and sewage-sludge samples, Plant Soil, 44, 505-509, 1975.
Wallschläger, D., Desai, M. V. M., and Wilken, R.-D.: The role of humic substances in the aqueous mobilization of mercury from contaminated floodplain soils, Water Air Soil Poll., 90, 507-520, 1996.

Wallschläger, D., Desai, M. V. M., Spengler, M., Carvalhinho Windmöller, C., and Wilken, R. D.: How humic substances dominate mercury geochemistry in contaminated floodplain soils and sediments, J. Environ. Qual., 27, 1044-1054, 1998.

Weber, J. H.: Review of possible paths for abiotic methylation of mercury (II) in the aquatic environment, Chemosphere, 26, 2063-2077, 1993.

Wegener, G., Shovitri, M., Knittel, K., Niemann, H., Hovland, M., and Boetius, A.: Biogeochemical processes and microbial diversity of the Gullfaks and Tommeliten methane seeps (Northern North Sea), Biogeosciences, 5, 1127-1144, doi:10.5194/bg-51127-2008, 2008.

White, D. C., Davis, W. M., Nickels, J. S., King, J. D., and Bobbie, R. J.: Determination of the sedimentary microbial biomass by extractable lipid phosphate, Oecologia, 40, 51-62, 1979.

Windham-Myers, L., Marvin DiPasquale, M., Krabbenhoft, D. P., Agee, J., and Cox, M. H.: Experimental removal of wetland emergent vegetation leads to decreased methylmercury production in surface sediment, J. Geophys. Res., 114, G00C05, doi:10.1029/2008JG000815, 2009.

Wolfe, M. F., Schwarzbach, S., and Sulaiman, R. A.: Effects of mercury on wildlife: A comprehensive review, Environ. Toxicol. Chem., 17, 146-160, 1998.

Wu, H., Ding, Z., Liu, Y., Liu, J., Yan, H., Pan, J., Li, L., Lin, H., Lin, G., and Lu, H.: Methylmercury and sulfate-reducing bacteria in mangrove sediments from Jiulong River Estuary, China, J. Environ. Sci., 23, 14-21, 2011.

Wupperverband: FluGGS: FlussgebietsGeoinformationsSystem der Wupperverbandes, http://fluggs.wupperverband.de/internet/ initParams.do, Cited 15 Dec 2009.

Yin, Y., Allen, H. E., Huang, C. P., and Sanders, P. F.: Effects of pH, chloride and calcium(II) on adsorption of monomethylmercury by soils, Environ. Toxicol. Chem., 16, 2457-2462, 1997.

$\mathrm{Yu}, \mathrm{K}$. and Rinklebe, J.: Advancement in soil microcosm apparatus for biogeochemical research, Ecol. Eng., 37, 2071-2075, 2011.

Yu, K., Böhme, F., Rinklebe, J., Neue, H.-U., and DeLaune, R. D.: Major biogeochemical processes in soils - A microcosm incubation from reducing to oxidizing conditions, Soil Sci.Soc. Am. J., 71, 1406-1417, 2007.

Zelles, L.: Phospholipid fatty acid profiles in selected members of soil microbial communities, Chemosphere, 35, 275-294, 1997. 